\title{
ARCHEOLOGICKÉ NÁLEZY Z DƯLNÍCH AREÁLŮ 16. STOLETÍ V JÁCHYMOVĚ
}

\author{
PAVLÍNA SCHNEIDERWINKLOVÁ - ONDŘEJ MALINA - MARKÉTA AUGUSTÝNOVÁ
}

\begin{abstract}
Abstrakt: Př́spěvek je věnován výpovědní schopnosti archeologických, ikonografických a písemných pramenů z 16. století pro poznání nemovitého zázemi a projevu hmotné kultury v prostředi stř́brorudných doli̊ horního revíru Jáchymov. Srovnáni těchto pramenů přináši zajímavý pohled do prostředi di̊lní krajiny a každodenniho života horniků v obdobi 16. století.
\end{abstract}

Kličová slova: hornictví-Jáchymov - novověká keramika-16. století.

\section{Archaeological finds from 16th-century mining areas in Jáchymov}

Abstract: This contribution discusses the informative potential of archaeological, iconographic and written sources from the 16th century for the study of the hinterland and manifestations of material culture in the environment of silver mines of the upper mining area in Jáchymov. The comparison of these sources provides an interesting insight into the mining landscape and everyday life of miners in the 16th century.

Key words: mining - Jáchymov - modern-age pottery - 16th century.

Královské horní město Jáchymov a těžba jeho stříbrnorudného ložiska zasáhla v 16. století velmi razantně dosud jen málo dotčenou krajinu lidskými aktivitami. Postupem času však slábnoucí vliv antropogenních aktivit zde umožnil dochování unikátního komplexu montánní krajiny. Role Jáchymova v dění na domácím i mezinárodním poli v oblasti kulturního, hospodářského i politického života je pro celé 16. století nepopíratelná. Jeho odkazu bylo věnováno již mnoho pozornosti z řad různých př́rodovědných a historicko-technických oborů (např. sborník Dolování v Jáchymově 1516-1966. Rozpravy Národního technického muzea. Sv. 26. Praha 1967; 450 let jáchymovských dolů. Sborník pro dějiny př́irodních věd a techniky. Sv. 12. Praha: Academia, 1967; Proměny montánní krajiny, historické sídelní a montánní struktury Krušnohoří. Loket: Národní památkový ústav v Lokti, 2013), bohužel však minimálně ve sféře archeologie (Malina 2015; Volf a kol. 2016). Jeden mimořádný pramen poznatků stál dlouho v pozadí zájmu, a to unikátně zachované terénní relikty těžebních areálů v téměř kompletním prostorovém rozsahu původního historického stříbrnorudného revíru. Význam komplexu důlní krajiny tkví v ucelenosti a relativně dobře zachovalém stavu reliktů. Potenciál tohoto revíru však řadu let nelákal pouze vědeckou obec, ale i jiné komerční aktivity, zejména pak nelegální rabující detektoráře. Nejvyšší intenzitu měla detektorářská činnost v období konce 90 . let minulého století a byla pak jedním z hlavních podnětů k provedení rozsáhlého archeologického nedestruktivního výzkumu formou terénního průzkumu, proběhlého mezi lety 2003-2010 na vybraných lokalitách západního Krušnohoří. Významným př́nosem terénního průzkumu byl, mimo jiné, i zisk souboru movitých artefaktů. Jejich přítomnost přímo v reliktech důlních děl není u tohoto typu objektů pravidlem. Je to spíše výjimka, jejíž význam je pak o to větší, máme-li k archeologicky sledovanému prostoru $\mathrm{k}$ dispozici také prameny jiné povahy. $\mathrm{V}$ tomto př́padě se jedná o autentické písemné a ikonografické materiály. Tento příspěvek se věnuje vzájemné komparaci výpovědních schopností archeologických, písemných a ikonografických pramenů a propojení jejich informačního potenciálu. Cílem př́íspěvku je poznání vlastní důlní zástavby a projevu každodenní hmotné kultury přímo na důlních pracovištích v průběhu 16. století v těch částech jáchymovského stř́brnorudného revíru, které nebyly konfrontovány s vlastní sídelní zástavbou horního města Jáchymova.

První část prríspěvku představuje přírodní prostředí lokality s důrazem na geologicko-ložiskovou situaci a historický vývoj těžebních prací. Další část je zaměřena na deskripci a vyhodnocení nálezových situací a souborů movitých artefaktů. Třetí část přináší rozbor vybraných písemných a ikonografických pramenů ke zvolenému tématu a následné vzájemné komparaci se věnuje poslední, čtvrtá část. 


\section{Př́ŕrodní poměry lokality a nástin vývoje těžebních prací}

\subsection{Př́rodní poměry lokality}

Jáchymovský rudní revír se rozprostírá na území západního Krušnohoří. Poměrně ostře stoupající terén Krušnohorského masivu směrem k božídarské planině s nejvyšším vrcholem Klínovec (1 $244 \mathrm{~m}$ n.m.) je rozbrázděn řadou úzkých a hlubokých údolí s drobnými vodotečemi. Původní historické jádro města Jáchymov (okr. Karlovy Vary) se rozprostírá v ostře zaříznutém údolí Jáchymovského potoka, lemovaném na západní straně svahy vrchů Hřeben $(986 \mathrm{~m} \mathrm{n}$. m.) a Čimický vrch (934 m n. m.), východní stranu pak tvoří svahy vrchů Šance $(927$ m n. m.) a Stráž (840 m n. m.). Vlastní členitý reliéf výše uvedených svahů nesl v minulosti dílčí a vlastní pojmenování, například Klínovec (původně Keilberg), Uhelný vrch (původně Kohlberg), Zámecký vrch (původně Schottenberg) ad. Ve spodní části města se do Jáchymovského potoka zleva vlévá Klínovecký potok. Historické jádro města bylo koncipováno jako ulicová zástavba podél hlavní trasy komunikace, lemované otevřeným prostranstvím, z něhož pod svahy Zámeckého vrchu (původně Schottenbergu) vybíhalo náměstí s původní historickou radnicí a Chlebným trhem (dnes náměstí Na Slovanech) a přecházelo táhle do horní části města s královskou mincovou, školou, farou a hlavní dominantou města, protestantským kostelem sv. Jáchyma (k tomu více Zeman 2016).

V této oblasti se počátkem 16. století rozprostíralo táhlé zalesněné území pohraničního hvozdu a díky tomu ani nebyl rozsah revíru v počátečním období nijak limitován. Jeho rozloha byla nejprve dána prostorovým rozsahem kutacích/průzkumných prací a získáváním nových lesních pozemků. Celkový rozsah se tak několikrát měnil a upřesněn byl až počátkem 30 . let se vznikem nových sousedních báňských revírů Horní Blatná a Boží Dar (Majer 1968, 141-142; Ministr 1962, 207-208). Předmětem nejstarší těžby byly především rudy stříbra, ložiskově vázané na dvě žilné struktury pětiprvkové dvoufázové formace $\mathrm{Ag}-\mathrm{Co}-\mathrm{Ni}-\mathrm{Bi} \pm \mathrm{U}$, probíhající zhruba ve směrech sever-jih a východ-západ. Mocnost žil se pohybovala od $10 \mathrm{do} 30 \mathrm{~cm}$ a směrná délka byla v závislosti na žilných strukturách od několika stovek metrů po dva kilometry. Těžba stříbra byla posléze doplněna o těžbu rudy vizmutu a kobaltu, později ještě i o rudy arsenu a uranu (více Ondruš a kol. 2003; Horák 2000; Kořan 1967, 51). Jelikož jáchymovské žilné zrudnění je charakteristické proměnným mineralogickým složením v návaznosti na hloubku zrudnění, rozloha revíru se během jednotlivých period těžby v zásadě téměř neměnila a lze ji geograficky vymezit spojnicemi mezi současnými obcemi Suchá - Arnoldov - Popov - Hřebečná - kóta Špičák a Klínovec - Suchá (Majer 1968, 115).

\subsection{Počátky a rozvoj těžebních prací}

Horská oblast česko-saského západního Krušnohoří byla nejpozději od poloviny 14. století známá především díky ložiskům cínu a železa. Rýžovnické cínařské provozy a sporadická hlubinná těžba cínu či železa však nebyly tak intenzivní (Jangl 1968, 25-26). Změna přišla teprve v průběhu druhé poloviny 15 . století v souvislosti s intenzivní prospektorskou činností pátrající po bohatých ložiscích stříbra, díky níž povstaly např́íklad stř́brné doly u Schneebergu a Annabergu (Hemker-Burghardt-Hönig 2014, 55). Nové nálezy ložisek stříbra nezůstaly na české straně hor bez odezvy a v prvním desetiletí 16. století došlo k objevu jáchymovského ložiska (Lorenz 1925, 36).

Prudké jižní svahy Krušných hor pokrývaly až do průběhu 16. století husté hraniční hvozdy, které byly na svazích lokálně přerušeny menšími sídelními jednotkami. Ty vznikly jako výsledek pozdní kolonizace méně úrodných oblastí konce 13. až první poloviny 14. století (Majer 1968, 137; Klír 2016, 330). K těmto novým kolonizačním osadám patřila i malá osada Konradsgrün v údolí Jáchymovského potoka. V roce 1434 získal do zástavy celé loketské panství zemský kancléř Kašpar Šlik a v průběhu 15. století pak pozemková držba prostoru budoucího města Jáchymova přešla na ostrovskou větev rodu Šliků. Roku 1498 je Konradsgrün uváděn jako opuštěný a k roku 1516 z této osady zůstal v provozu jen hamr a obilní mlýn (Urban 1987, 61; Lorenz $1925,1)$. Ostatně jak hovoří Mathesius o stavu krajiny v době založení Jáchymova: „Předtím 
$v$ tomto a kolem tohoto Údoli byla převeliká divočina, v níž Ostrovští a Míšenští také od dávna dolovali (...)“ (Urban 1981, 144).

První písemnou zmínku o výskytu stříbrných žil v jáchymovském údolí zaznamenal Jan Schönstetter roku 1510 v chebské kronice. K roku 1512 je následně kladen nález opuštěné stříbronosné štoly ostrovským radním Öesserem a horníkem Kašparem Bachem z Geyeru u Konradsgrünu, později pojmenované jako Nálezná štola, tj. Fundgruben Stollen (Nemeškal 1964, 22-24). Jejich práce ale netrvaly dlouho a důl byl již před rokem 1516 opuštěný. O tom se zmiňuje Agricola: „(...) zde byla jen jediná důlní bouda, která stála u staré polozasypané jámy (...) hrabě Alexander Leisning, baron Wolfgang Schönburg, pan Štěpán Šlik a člen z rodiny Thumsirnů (...) se rozhodli obnovit tento starý důl" (Reiniš 1957, 71). Z dobových písemných zpráv a z postupu a charakteru prací od roku 1516 je zřejmé, že předchozí občasné pokusy o těžbu se odehrávaly pouze na velmi malém prostoru poblíž spodní části údolí a v malé intenzitě. $\mathrm{Na}$ řádné vedení důlních prací před rokem 1516 chyběly hlavně finance, jak o tom hovoří jasně další citace z Mathesia: „Dřive ně̌ vzešlo Údolí, jeden horník z Geyeru, Kašpar Bach zvaný a starý Oeser z Ostrova nad Ohři razili štolu do Zámeckého vrchu, na staré nálezné jámě. Protože však na ni sami byli príliš slabí, zůstala tato štola ležet (...)“ (Urban 1981, 72). ${ }^{1}$ Tento stav by i odpovídal celkově špatné hospodářské situaci českých zemí a prázdné královské pokladny za vlády posledních Jagellonců (Macek 2001, 158).

Hlavní období těžebních prací na stříbrných žilách začalo roku 1516. V čele ostrovské větve rodu byl toho času Štěpán Šlik. Díky jeho iniciativě a pomoci přátel ze Saska se mu podařilo sestavit počátkem roku 1516 dostatečně finančně silné těžařstvo (viz výše). Na jaře téhož roku byly obnoveny práce $\mathrm{v}$ opuštěné štole, v níž dolovali Bach a Öesser na úpatí Zámeckého vrchu (dříve Schöttenberg), později nazývané Nálezná, a brzy se dostavil slibný výsledek, ač žíla nepatřila zrovna k těm nejbohatším (Lorenz 1925, 4). Následně se Štěpán Šlik obrátil na saské důlní odborníky, mezi nimi i na Jindřicha Könneritze, pozdějšího jáchymovského vrchního hormistra a mincmistra. Ti si 22. července 1516 prohlédli údolí a podali pozitivní stanovisko k vybudování horního města (k tomu více Nemeškal 1964, 27). Finanční oporou pro vybudování potřebného zázemí a počáteční rozvoj důlních prací byly Štěpánu Šlikovi norimberské obchodní domy Nützelů a Welserů, kam také podle smlouvy z roku 1518 plynuly první dodávky stř́íbrných rud jako dohodnutá forma splátek (Nemeškal 1964, 33).

Právní oporou a řádem bylo pro první dva roky obecně platné Ius Regale Montanorum. Díky inovativnímu přistupu Šliků obdržel roku 1518 Jáchymov vlastní báňský řád, který vycházel z moderně pojatého annaberského horního řádu (Jangl 1978, 2-3). Významným krokem pak bylo vydání druhého šlikovského řádu roku 1541, který již plně čerpal z potřeb vlastní jáchymovské důlní praxe a roku 1548 byl s nepatrnými úpravami znovu vydán královskou komorou jako královský jáchymovský horní řád (Kořan 1967a, 15; Jangl 1978, 3-5). Během 16. století mezi českými a saskými revíry západního Krušnohoří obecně panovala vzájemná fluktuace pracovních sil a aktivní komunikace mezi báňskými a hutními odborníky (Lorenz 1925, 36).

Vývoj celého sídelního komplexu byl překotný a vzestup těžby $\mathrm{v}$ přímé úměře přinášel i růst počtu obyvatel (Hofmann 1987, 76). Kupř́ikladu mezi lety 1518 a 1524 se udělovalo ročně kolem 500 až 700 propůjček (Majer 1968, 146). Postup prospekčních prací musel být velmi rychlý a bylo do něj již od počátku zapojeno i velké množství havírư, jak je patrné z důrazu na přesné zapsání dne i hodiny, kdy byla žádost o propůjčku podána a žadateli vystaveno potvrzení (viz Jangl 1979, 120 čl. 5). Podle prvního jáchymovského horního řádu (1518) byly propůjčky potvrzovány až po pozitivním nálezu žíly nebo nadějné pukliny, a to do 14 dnů po podání žádosti o propůjčku. Jinak žádost o propůjčku zanikla (Jangl 1979, 121 čl. 6).

Přírůstek obyvatel města dosáhl roku 1534 svého maxima, uvádí se kolem 18000 obyvatel, kteří obývali na 1200 obytných domů a k tomu zde bylo ještě 100 cechovních domů (Lorenz 1925, 39). Počet důlních děl k roku 1544/1545 dosáhl celkem 944 šachet a štol, v nichž bylo zaměstnáno kolem 8000 havírůn, přibližně 400 směnmistrů a jiných úředníků a 800 důlních

1 Termín „nálezná jáma“ je název pro základní důlní míru, propůjčovanou prvnímu nálezci zrudněné žíly (Jangl 2006, 44). 

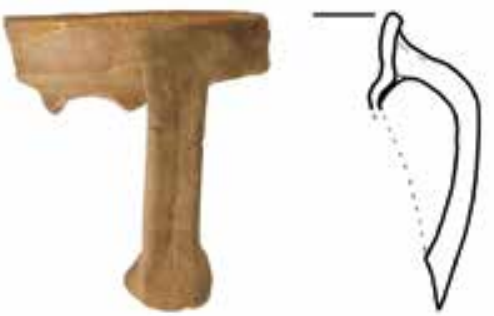

1
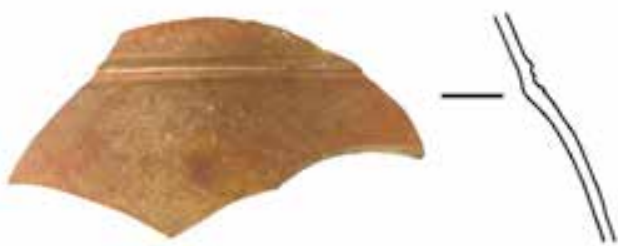

4
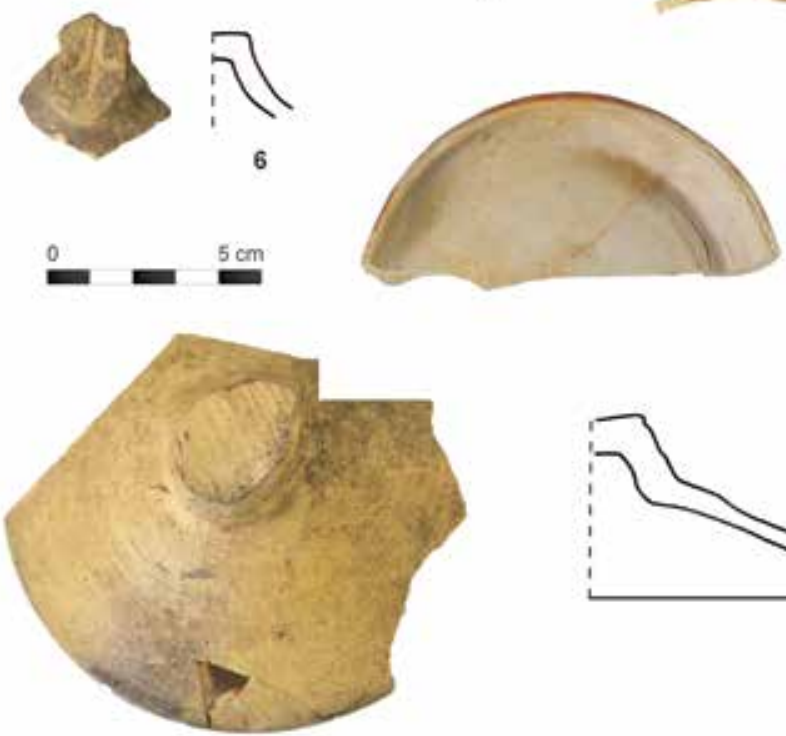
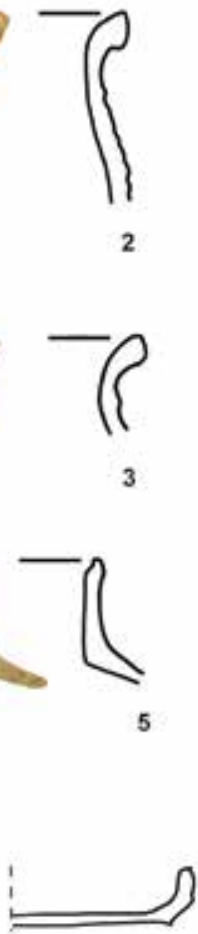

2

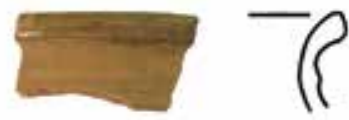

3

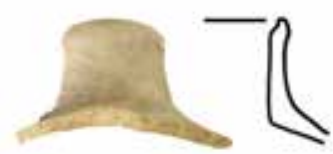

5

Obr. 1. Keramické nálezy, výběr: 1 - 3/03 (JACH103); 2 - 2/03 (JACH102); 3 - 9/05 (JACH103); 4 - 2/03 (JACH304); 5 - 3/03 (JACH302); 6 - 2/03 (JACH106); 7 - 2/03 (JACH304); 8 - 3/03 (JACH104).

Abb. 1. Keramikfunde, Auswahl: 1 - 3/03 (JACH103); 2 - 2/03 (JACH102); 3 - 9/05 (JACH103); 4 - 2/03 (JACH304); 5 - 3/03 (JACH302); 6 - 2/03 (JACH106); 7 - 2/03 (JACH304); 8 - 3/03 (JACH104).

dozorců. Ruda byla zpracovávána téměř nepřetržitě ve třinácti hutích (Majer 1968, 156). Právě období 30. a 40. let 16. století vykazovalo největší prosperitu těžby, jež se promítla i v urbanismu města. Do této doby se hlásí hlavní proud zděné výstavby patricijských a veřejných staveb v módním saském renesančním duchu, u ostatní zástavby pak zůstává forma celodřevěné nebo hrázděné konstrukce (Rada 1958, 31).

Charakter samotné exploatace se od středověku př́liš nelišil a sestával v převážné míře z maloprovozů. Pro období 1516-1545 se zaměstnávaly na $54 \%$ důlních provozů maximálně trri osoby. Kolem $30 \%$ dolů disponovalo počtem do deseti osob a ve zbývajících $16 \%$ důlních 


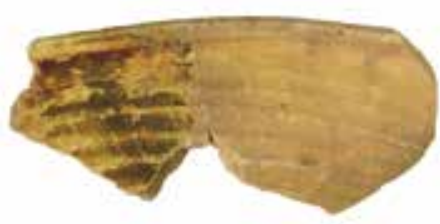

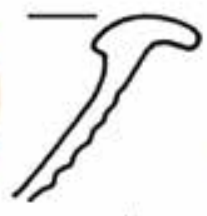

1
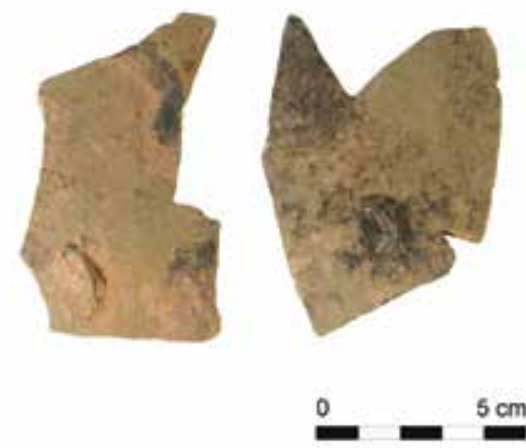
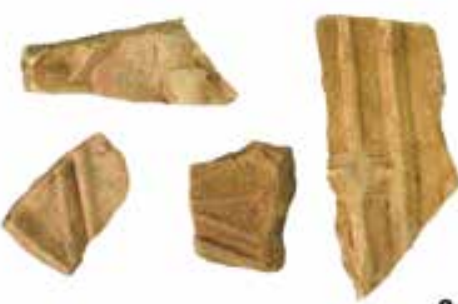

2
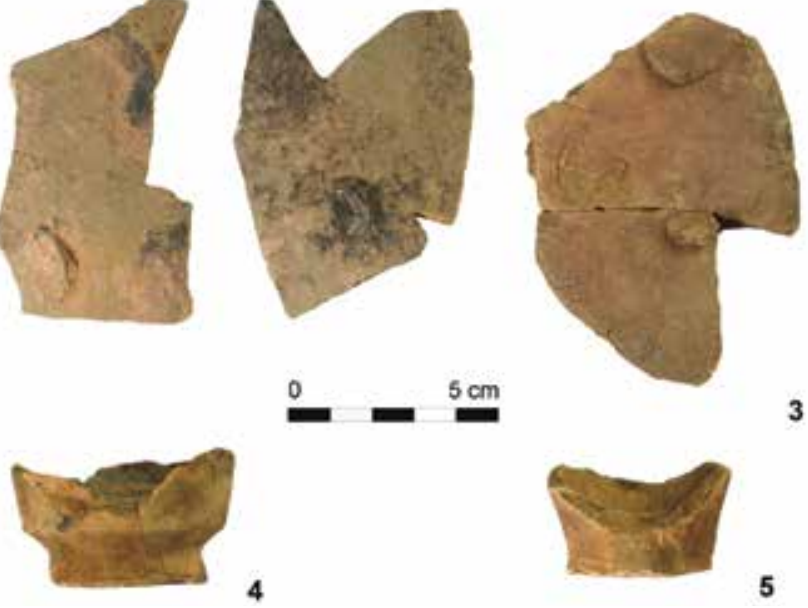

3

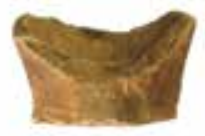

5

Obr. 2. Keramické nálezy, výběr: 1 - 3/03 (JACH202); 2 - 2/03 (JACH202 a 203); 3 - 3/03 (JACH401); 4 - 2/03 (JACH404); 5 - 2/03 (JACH403).

Abb. 2. Keramikfunde, Auswahl: 1 - 3/03 (JACH202); 2 - 2/03 (JACH202 und 203); 3 - 3/03 (JACH401); 4 - 2/03 (JACH404); 5 - 2/03 (JACH403).

podniků pracovalo více než deset lidí s maximálním stropem 90 až 150 zaměstnanců (Majer 1967, 138). Hlavní strategií těžebních prací zůstával extenzivní styl ražby s rychlým postupem do hloubky (Parma 1970, 60). Díky tomu byl průběh každé žíly rozdělen na velké množství propůjček, a tím pádem i těžen větším počtem dolů. Na žilách se propůjčovalo hlavně podle schématu annaberského řádu. V místě prvního nálezu zrudněné žíly, tj. od středu nálezné šachty, se vyměřila první míra, tzv. Nálezná jáma o velikosti přibližně $84 \times 14 \mathrm{~m}$, resp. $42 \times 7$ láter, od níž se na obě strany po směru žíly vyměřovaly další propůjčky o velikosti zhruba $56 \times 14 \mathrm{~m}$, resp. $28 \times 7$ láter (Jangl 2006, 51). Hlavními těžními důlními díly byly šachty, ovšem výrazná geomorfologie terénu umožnila ložisko otevř́ít také velkým množstvím mělkých štol a zároveň přispěla k možnosti dobrého odvodnění systémem několika hlubokých dědičných štol (Majer 1968, 128). Velikosti vlastních dolových polí byly často malé, zpravidla si těžaři propůjčovali jednu až dvě výměry, výjimečně více (Jangl 1968, 28). Těžba ložiska stříbra probíhala tradičním sestupkovým způsobem po úklonu ložiska (Parma 1962, 138). Dobývání bylo tzv. selektivní př́mo v dole se z natěžené rudy vybíraly rentabilní kusy a zbylá chudší ruda se zvlášt' vyvážela spolu s jalovou hlušinou na haldu. Metoda těžby se nazývá tzv. na zával, tj. vyrubané úseky se nevyztužovaly, $v$ př́ípadě nutnosti a po schválení hormistra se mohly zasypávat jalovou hlušinou (Zámek 1989; Jangl 1978, 40 čl. 24). Brzy byly známy i úložné poměry na jáchymovském ložisku a horníci ze zkušeností věděli, že nejvíce rudy se láme v hloubkách kolem $60-80 \mathrm{~m}$, v zóně cementačního pásma, i když bohaté nálomy jsou známy i z povrchu. Na nejbohatších žilách dosahovala těžba hloubek pod 150 m (Urban 1981, 123; Reiniš 1957, 79). Největší počet důlních podniků v rámci celého revíru byl soustř̌eděn na Zámecký vrch / Schottenberg, Türckner / kóty 


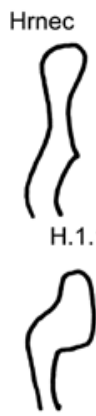

H.5.1

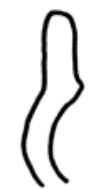

H. 1.2

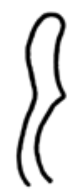

H.1.3

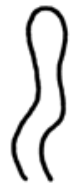

H.1.4

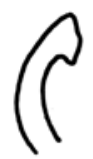

H.2.1

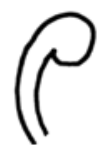

H.3.1

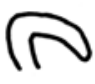

H.4.1

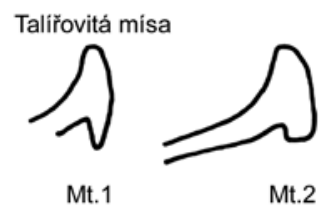

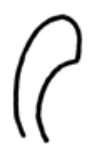

H.6.2

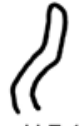

H.7.1

Taliřovitá misa

Mt.

Mt.2

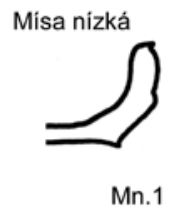

Lahev

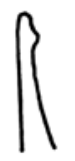

L. 1

Poklice
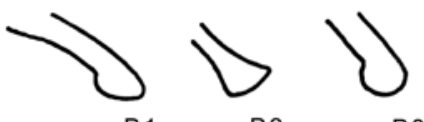

P.2

P.3

Dno

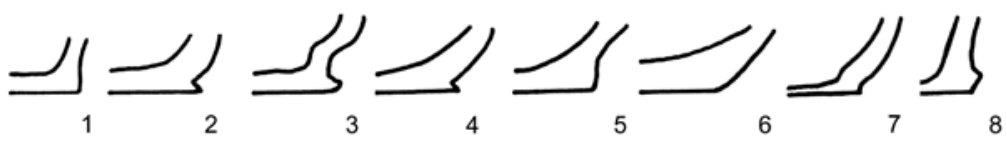

Kachle, napojeni ČVS

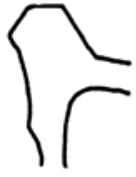

1.1.1

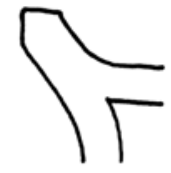

1.1.2

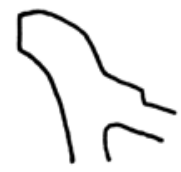

1.1 .3

Kachel nádobkový
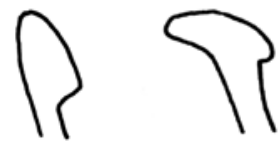

Obr. 3. Typáŕ profilací.

Abb. 3. Typentafel der Profilierungen.

Stráž až Šance a na návrší Hřeben / Niklasberg. Na posledním jmenovaném návrší bylo také v 16. století dosaženo největší hloubky těžby v revíru - 395 m (Majer 1967, 140, 144, obr. 1).

V průběhu 40. let 16. století byly objeveny již všechny žíly a odžilky. Zároveň postupem do větších hloubek u dříve těžených žil narůstaly náklady na provoz dolů a snižoval se také obsah stříbra v rudě. Situace se i nadále zhoršovala a těžební práce pokračovaly ve druhé polovině 
16. století pouze v okolí a ve směru dědičných štol (Majer 1967, 160). K tomu se přidaly negativní hospodářské faktory a na konci 80. let hrozilo téměř úplné zastavení důlních prací (Majer 1967a, 134). Báňský provoz se pak udržel pouze na dědičných štolách, jejichž existence byla pro revír existenční nutností, přičemž Jáchymov si mohl ponechat výsady a užitky plynoucí z titulu horního města (Kořan 1967a, 19-20). Doly i město zůstaly pod správou Šliků až do roku 1545, poté přešly do královského majetku (Nemeškal 1964, 128).

\section{Výsledky archeologického výzkumu}

Archeologický nedestruktivní výzkum formou terénního průzkumu z let 2003-2010 byl zaměřen na ověření archeologického potenciálu nemovitých reliktů a na dokumentaci a ohledání výkopů po nelegální detektorářské činnosti. Průzkum probíhal v lesním prostředí, převážně tvořeném plně zapojenou vzrostlou smrkovou monokulturou, na kamenitých svazích doplněnou porostem bučin. Při terénních pracích nebyl použit detektor kovů a nalezené výkopy byly začištěny pro lepší viditelnost kontextu, jeho popis viz níže. Archeologické situace lze podle zásahu rozdělit do dvou skupin, vyvolané a) antropogenní činností a b) prŕírodní činností. K antropogenním zásahům patří nelegální detektorářské výkopy (sondy 3/03, 2/04, 7/05, 9/05), lesnické aktivity (sonda 3/04) a stavební aktivity (sonda 10/05). K př́rodním zásahům vyvolaným povětrnostními podmínkami lze přiřadit vývraty (sondy $2 / 03,6 / 04$ ). Jedním z výsledků bylo získání mimořádného souboru movitých artefaktů, jejichž podstatná část pochází z prostoru bývalého jáchymovského stříbrnorudného revíru. Stručný přehled jednotlivých souborů je uveden v př́loze (viz tab. 2), v níž je pro další práci s historickými prameny uváděna i lokalizace na dané rudní žíle.

Význam souboru nálezů $\mathrm{z}$ tohoto revíru tkví spíše $\mathrm{v}$ kvalitě dat nežli v jejich kvantitě. V těžebních areálech byly všechny zjištěné nálezové situace s movitými artefakty v přímé vazbě na relikty nadzemních částí důlních děl, tj. na haldy vytěžené hlušiny (obr. 10). Hlušinová halda byla vždy nadzemní součástí dolu společně s ohlubní šachty nebo ústím štoly, případně povrchové dobývky, a byla vršena do podoby odvalu nebo obvalu. Ohlubně šachet a ústí štol podléhají zpravidla při absenci údržby - rychlé destrukci ve formě viditelných propadů nebo zařícení/ zasutí. A tak haldy hlušiny jsou často jediným původním nedestruovaným pozůstatkem těžby.

Hlušinové haldy jsou ve sledovaných prrípadech v původní plné kubatuře s dobře patrnou původní pochozí plochou na temeni, případně zmenšenou zřícením úvodní šachty do podzemí. Na haldy se vedle vytěžené boční horniny (jaloviny) žil také ukládala pečlivě vyseparovaná chudá rudnina a zůstávala zde jako zásoba pro horší časy. Těžaři měli podle obou jáchymovských báňských řádů především všeobecnou povinnost pokračovat v pracích do hloubky a nesměli přebírat starší natěžené haldy do doby úplného vyčerpání ložiska (Jangl 1978, 39 čl. 21; 1979, 125 čl. 21). K přebírání hald docházelo až teprve tehdy, když vlastní důlní díla již nebyla z povrchu přístupná a zároveň nastal zájem o rudy, které $\mathrm{v}$ předchozí době nebyly $\mathrm{v}$ popředí zájmu (názorně Jangl 1972, 70). Tyto aktivity pak viditelně částečně narušily některé haldy.

Samotné prostředí nálezů, tj. vlastní těleso navršené hmoty haldoviny, je v podstatě také pozitivní nálezovou situací, hodnotíme-li to z hlediska projevů lidské činnosti. Nicméně pro větší efektivitu je nutno hledat na těchto projevech situace, které zaznamenávají či obsahují ještě další stopy po lidské činnosti. Těmi jsou v haldovinách např́íklad nahodilé movité nálezy či dochované původní úrovně terénu obsahující movité nálezy nebo pozůstatky po nemovitých stavbách.

Souhrnně lze ve většině sond, tj. vyjma sond 6/04 a 7/05, zaznamenat shodnou nálezovou situaci, tvořenou lesním drnem s hrabankou, dále hlinitou uloženinou šedožluté až nahnědlé barvy s movitými artefakty, která pozvolna přechází v haldovinu. ${ }^{2}$ Mocnost kulturní vrstvy dosahuje pouze několika centimetrů. U artefaktů z této uloženiny není výjimečný jejich rozptyl

2 Haldovina/hlušina - označuje nesoudržnou, ulehlou uloženinu z lomových kamenů (tj. jalové boční horniny a žiloviny) s příměsí hlinité složky. Druh, velikost a množství kamenité složky jsou podmíněny geologicko-mineralogickou stavbou ložiska a jsou výsledkem působení chemicko-fyzikálních změn vlivem povětrnostních podmínek na povrchu. Velikost kamenité složky je odrazem techniky těžby a stupněm třídění vytěžené rubaniny (Zámek 1989, 54). 


\begin{tabular}{|c|c|c|c|c|c|c|c|c|c|c|c|c|c|c|c|c|}
\hline & \multicolumn{3}{|c|}{ kachle } & \multicolumn{5}{c|}{ kamenina } & \multicolumn{5}{c|}{ hrnčina } & \multicolumn{3}{c|}{ keramika technická } \\
\hline soubor & 202 & 203 & 206 & 301 & 302 & 304 & 305 & 101 & 102 & 103 & 104 & 106 & 401 & 402 & 403 & 404 \\
\hline $2 / 03$ & 8 & 3 & 1 & & & 8 & & 70 & 6 & 6 & 7 & 5 & & & 1 & 1 \\
\hline $3 / 03$ & 8 & & 1 & & 3 & 1 & 1 & 34 & & 12 & 11 & & 10 & 1 & & \\
\hline $2 / 04$ & 2 & & & 2 & 2 & 3 & & 23 & 1 & 1 & 5 & & & & & \\
\hline $7 / 05$ & & & & & & & & 3 & & 1 & & & & & & \\
\hline $3 / 04$ & & & & & & & & 2 & & 1 & 1 & & & & & \\
\hline $9 / 05$ & & & & & & & & 4 & & 2 & & & & & & \\
\hline $6 / 04$ & 3 & & & & & & & & & 2 & 1 & & & & & \\
\hline $10 / 05$ & 4 & & & & & & & 7 & & & & & & & & \\
\hline
\end{tabular}

Tab. 1. Př́íslušnost zlomků k jednotlivým keramickým třídám.

Tab. 1. Zugehörigkeit der Bruchstücke zu den einzelnen Keramikklassen.

\begin{tabular}{|c|c|c|c|c|c|c|c|c|c|}
\hline soubor & lokalita & žilný tah & keramika & kachle & sklo okenní & železo & kost & uhlíky & struska \\
\hline $2 / 03$ & $\begin{array}{c}\text { Eliášské } \\
\text { údolí }\end{array}$ & žíla Geyer & 104 & 15 & & & & & \\
\hline $3 / 03$ & Hřeben & $\begin{array}{c}\text { žíla Johannes } \\
\text { Silbermüller }\end{array}$ & 73 & 9 & 8 & $\begin{array}{c}4 \\
\text { (hřebíky) }\end{array}$ & & ano & \\
\hline $2 / 04$ & Hřeben & $\begin{array}{c}\text { žíla Alte Rote } \\
\text { Gang }\end{array}$ & 37 & 2 & 1 & $\begin{array}{c}2 \\
\text { (hřebíky) }\end{array}$ & 2 & & \\
\hline $3 / 04$ & Neklid & dno údolí & 4 & & & & & & 6 \\
\hline $6 / 04$ & Seideltaich & neznámá žíla & 3 & 3 & & & & & \\
\hline $7 / 05$ & Hřeben & $\begin{array}{c}\text { žíla Johannes } \\
\text { Silbermüller }\end{array}$ & 4 & & & & & & \\
\hline $9 / 05$ & Hřeben & Žíla Elias & 6 & & & $\begin{array}{l}1 \text { (špička } \\
\text { želízka) }\end{array}$ & & & \\
\hline $10 / 05$ & $\begin{array}{c}\text { Eliášské } \\
\text { údolí }\end{array}$ & žíla Geyer & 7 & 4 & & & & & \\
\hline
\end{tabular}

Tab. 2. Početní zastoupení jednotlivých druhů nálezů.

Tab. 2. Häufigkeit der einzelnen Fundarten.

do vlastního tělesa haldy, v níž jsou v menší intenzitě obsaženy zpravidla do hloubky prvních dvaceti centimetrů. Jinou úlohu hrají movité artefakty zjištěné na různých místech haldoviny a v různých hloubkách přímo $\mathrm{v}$ haldovině bez doprovodné kulturní vrstvy. Ty jsou výsledkem provozu na díle, kdy archeologizace předmětu proběhla na náhodném místě po odhození (př́ípad artefaktů ze sond 6/04 a 7/05). Na získaných souborech je zřetelný silný dopad depozičních a postdepozičních procesů daných jednotvárností místa jejich uložení. Artefakty jsou velmi fragmentarizovány a jejich povrch je u keramických nálezů postižen silnou degradací a u kovových nálezů korozí. Velkou zásluhu na nálezovém stavu artefaktů má chemicko-fyzikální prostředí haldoviny.

\subsection{Vyhodnocení movitých nálezi̊}

Zpracování nálezových souborů proběhlo formou kódového zápisu všech typických atributů. Pro vyjádření technologicko-výrobních vlastností je použit princip třídění dle keramických tříd a popisu morfologicko-typologických informací (viz Nováček 2000, 12). Keramické tř́ídy jsou pro region západního Krušnohoří nově definovány a vycházejí z potřeb probíhajícího systematického archeologického zájmu o tuto oblast rámci projektu ArchaeoMontan 2018 (viz 


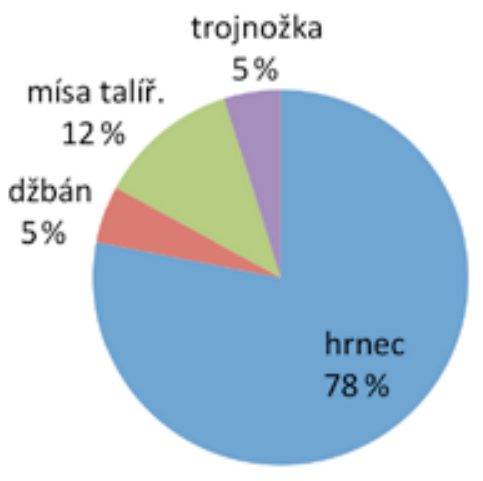

Graf 1. Tvary nádob - glazovaná hrnčina $(n=41$ zlomků). Diagramm 1. Gefäßformen - glasierte Töpferware $(n=$ 41 Bruchstücke).

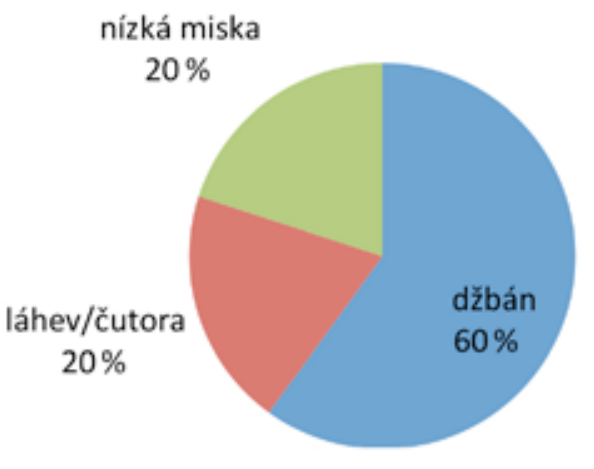

Graf 3. Tvary nádob - neglazovaná hrnčina $(n=7$ zlomků) Diagramm 3. Gefäßformen - unglasierte Töpferware $(\mathbf{n}=$ 7 Bruchstücke).

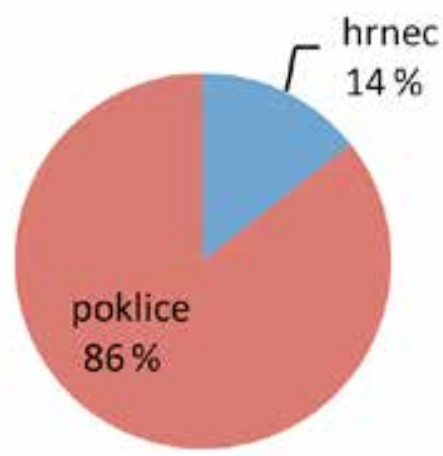

Graf 2. Tvary nádob - kamenina $(n=5$ zlomků). Diagramm 2. Gefäßformen - Steinzeug ( $n=5$ Bruchstücke).

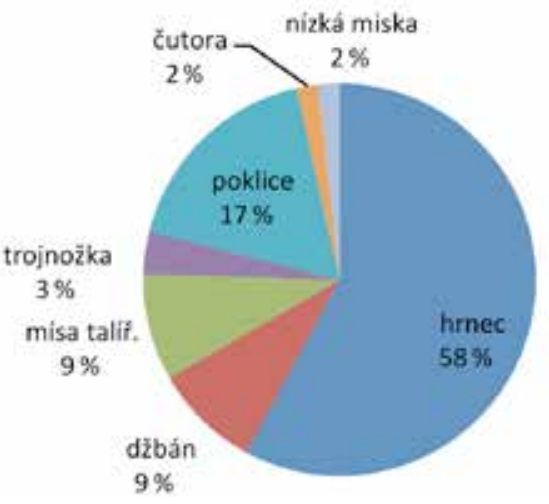

Graf 4. Souhrn všech tvarů keramického nádobí $(\mathrm{n}=$ 57 zlomků).

Diagramm 4. Zusammefassung aller Keramikgeschirrformen $(n=57$ Bruchstücke).

př́loha 1). Metodika zpracování je podřízena povaze sledovaných souborů. Ty jsou až na výjimky velmi malé velikosti, pocházejí z různých míst, ale jejich archeologizace proběhla za podobných podmínek a v téměř shodném prostředí. Užší zájem $\mathrm{v}$ rámci celku všech movitých nálezů je věnován bližšímu poznání keramické produkce, která hraje významnou roli v závěrečném vyhodnocení nálezových situací. Zpracování keramického materiálu je zaměřeno na hlavní podobu souborů, tj. informace $\mathrm{z}$ hlediska druhové skladby, materiálu a morfologie keramického zboží.

Movité soubory obsahují keramické zboží, které je možné rozčlenit do následujících kategorií (tab. 1): hrnčina (75\%), kamenina (8\%), technická keramika (5\%) a kachle (12\%).

\section{Kuchyňské a stolni keramické zboži}

Základní kuchyňský sortiment představuje oxidační hrnčina s vnitřní olovnatou glazurou (trrídy JACH101 až 103, celkem 101 zlomků; viz tab. 1). Tvarově patří toto zboží (graf 1) nejvíce hrncům $(78 \%)$, následně talířovitým mísám (12\%) a v menší míře džbánům a trojnožkám (po 5\%). Okraje hrnců jsou profilovány nejvíce do prožlabeného okruží (typ H.1.x, 22 zlomků), ostatní profilace jsou přítomny u několika málo zlomků nebo ojediněle (typ H.2.x až H.7.x). Okraje talírovitých mis (obr. 3) jsou nejčastěji tvarovány do typu Mt.1 (3 zlomky). Výzdoba 
je zaznamenána pouze ve dvou případech, kdy je vnější hrana okraje ozdobně promačkána do vlnovky nebo je dekor z malované linky na podhrdlí hrnce.

Tento výše popsaný glazovaný sortiment doplňuje oxidační neglazovaná hrnčina (trrída JACH104, 26 zlomků) a odlišuje se od něj pouze absencí olovnaté glazury. Toto zboží (graf 2) je tvarově spjato s poklicemi ( $86 \%$ ), v menší míře bylo zjištěno u hrnců (14\%). Poklice se zachovaly ve dvou fragmentech o průměrech 125 a $130 \mathrm{~mm}$ (obr. 1:8), hrnci patří modelace do kyjovitého okraje (obr. 1:3).

Minoritní množství náleží redukční režné keramice (třída JACH106, 5 zlomků), tvarově vázané pouze na poklice. V rámci typických zlomků se dochoval jeden okraj P.2. a tři knoflíky, z nichž jeden nese na horní ploše rytinu křižku (obr. 1:6). Knoflíky jsou zpravidla nízké, často oválného tvaru, mírně nepravidelné a anatomicky tvarované přesně pro pevné uchopení třemi prsty.

Kameninové výrobky (tř́ídy JACH301, 302, 304 a 305, celkem 20 zlomků) jsou tvarově reprezentovány především džbány (graf 3), k dalším výrobkům patří nízká miska - poklop a zlomek okraje z čutory / polní láhve (obr. 1:7, 5). Dna dosahují průměru 70-130 mm, odříznutá jsou strunou centricky (lasturovitá stopa) nebo jednosměrně. Produkce nalezených kamenin náleží k výrobnímu středisku Waldenburg. Pro chronologickou oporu je důležitý výskyt nízkého poklopu a čutory, jejichž výroba počínala během první poloviny 16. století a rychle vzrůstala v polovině druhé téhož století (Scheidemantel a kol. 2005, 284).

\section{Technická keramika}

Technické keramice je v souboru přiřazeno celkem 13 jedinců. Jedná se především o zlomky střední síly stěny válcovitého tvaru, opatřené prstovými výrůstky a s výraznými stopami přepálení (obr. 2:3). Dále do této kategorie patří dva téměř celé exempláře tzv. struskovacích střepů (obr. 2:4, 5). Posledním zlomkem je netradiční profilace těla menší nádobky do kónického tvaru. Pojem technická keramika vyjadřuje zboží, které je určeno ke konkrétnímu, specifickému výrobnímu procesu. Její výroba byla záměrně účelová, proto i její technologicko-výrobní vlastnosti i morfologie byly odlišné od běžné kuchyňské, resp. stolní keramické produkce. Na druhé straně se také pro různé technické procesy mohlo použít běžné neglazované hrnčiny (Vitouš 1974, 26).

\section{Doklady nemovitých staveb}

Nemovité objekty, kromě vlastních důlních děl, se v terénu nijak neprojevují a jejich existenci ukazují pouze některé druhy artefaktů, tj. movitých částí těchto staveb. Především se jedná o soubory kamnové keramiky, plochého okenního skla a drobných železných hřebíků. Kamnovou produkci reprezentují nádobkové (16 zlomků) a komorové (11 zlomků) kachle. Kachle jsou vyrobeny z jemné plavené kamnářské hlíny, oxidačně pálené a neglazované (JACH202, JACH203 a JACH206). Nádobkové kachle jsou čtverhranného ústí. Komorové kachle disponují čelní reliéfní neglazovanou stěnou (obr. 2:2) a ukazují vyspělou kachlovou produkci s motivy renesančního prostředí (srov. Žegklitz 2012). Ploché tabulové sklo je přítomno v podobě zlomků kruhových terčíků nebo plochých segmentů (celkem 9 zlomků) nazelenalé až téměř čiré barvy, na dvou jedincích s doklady po štípání. Několik malých zlomků železných hřebíků (6 zlomků) doplňuje celý soubor nálezů.

Výpověd' nálezů okenních skel (štípané segmenty či zlomky kruhových terčíků) a kachlů upozorn̆uje na existenci zástavby, po níž ovšem v terénu nezůstaly žádné relikty. Pouze zlomky hřebíků by mohly prozrazovat sbíjené dřevěné konstrukce, ale pro bližší poznání stavební podoby, konstrukčního řešení či velikosti staveb nejsou již v archeologických pramenech žádné další opory.

\subsection{Souhrnná zjištění v nálezovém fondu}

Všechny získané movité nálezy pochází z kontextů výlučně spjatých s důlním prostředím, tzn. s životem a prací na důlních dílech. Archeologizace všech nálezů se také odehrála v př́slušných odpadních uloženinách vzniklých po těžbě rud, tj. $\mathrm{v}$ haldovinách, př́ípadně v pozůstatku 


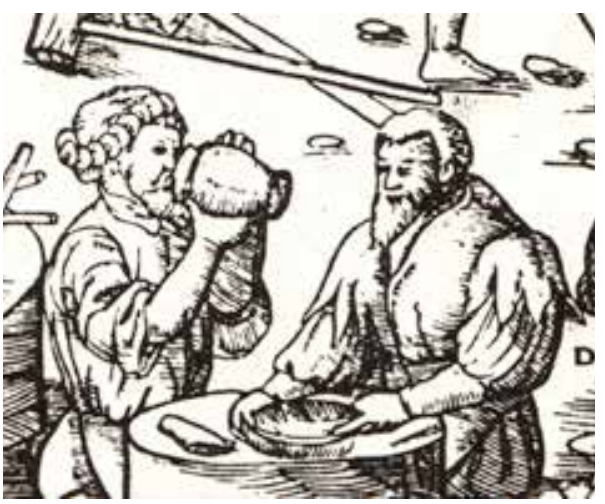

Obr. 4. Detail občerstvení. Podle Hummel a kol. 1933, 363. Abb. 4. Detail einer Erfrischung. Nach Hummel a kol. 1933, 363.

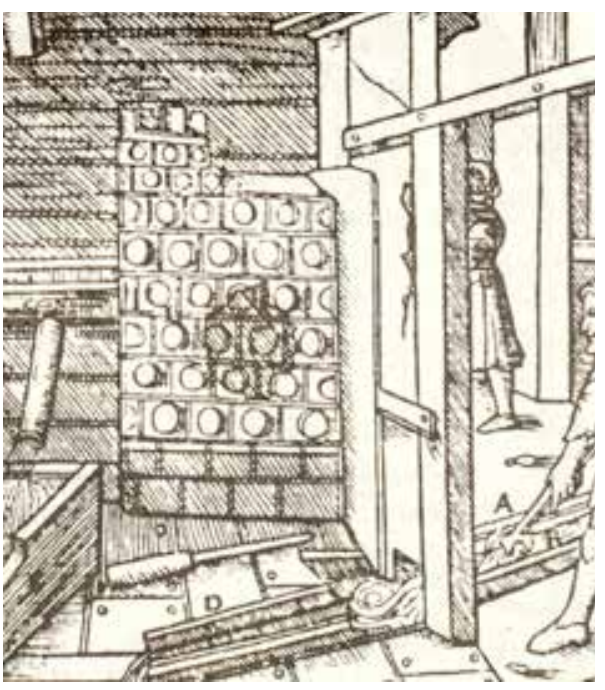

Obr. 6. Detail interiéru úpravny s kachlovými kamny. Podle Hummel a kol. 1933, 272.

Abb. 6. Detail des Innenraums einer Aufbereitungsanlage mit Kachelofen. Nach Hummel a kol. 1933, 272.

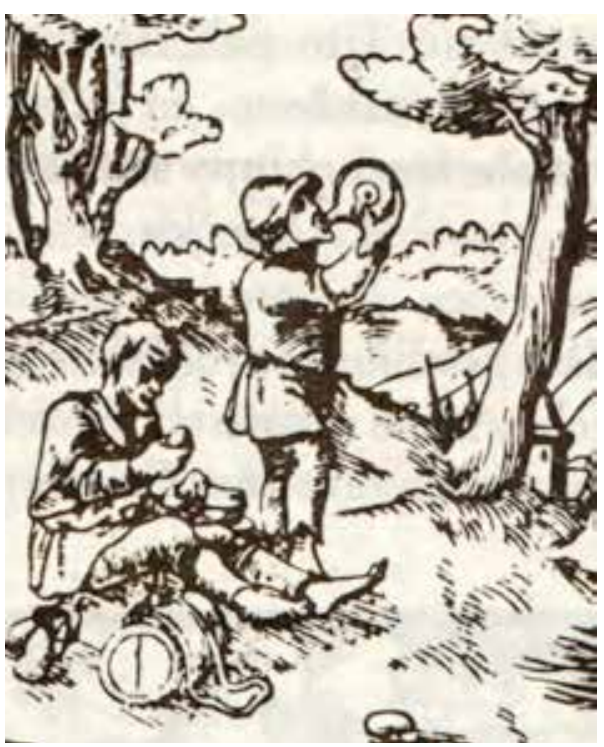

Obr. 5. Detail občerstvení s čutorou. Podle Hummel a kol. 1933, 285.

Abb. 5. Detail einer Erfrischung mit Feldflasche. Nach Hummel a kol. 1933, 285.

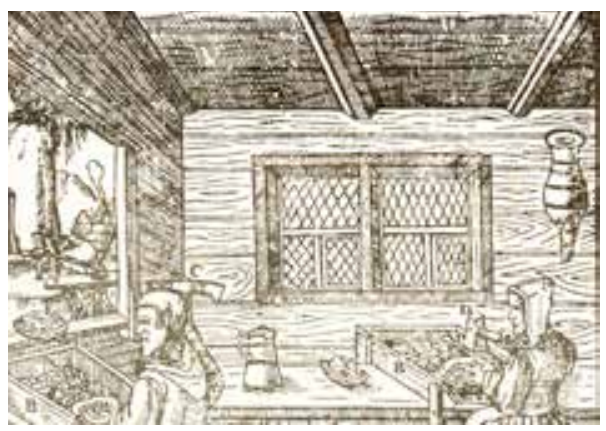

Obr. 7. Detail interiéru třídírny. Podle Hummel a kol. 1933 , 234.

Abb. 7. Detail des Innenraums einer Sortieranlage. Nach Hummel a kol. 1933, 234.

ne př́liš mocné kulturní vrstvy na pochozích plochách hald. Archeologická zjištění z terénu nezaznamenala jiné aktivity v místech učiněných nálezů, například sídelní, při nichž by mohlo dojít k narušení původního kontextu.

Výsledky zpracování hlavně keramických nálezů ukazují na první pohled patrný nesoulad výrobků hrnčin a kamenin. Vyskytuje se zde již úzká specializace obou skupin zboží na konkrétní tvarovou produkci určenou pro běžné užívání. K poznání celkové tvarové skladby keramické náplně souborů je nutné vycházet ze sloučení kamenin i hrnčin (graf 4). Tímto se ukazuje konkrétnější obraz o skladbě kuchyňského, resp. stolního souboru. Nepřekvapující je dominance univerzálních hrnců (58\%) s poklicemi (17\%) jako tradičního obalu potravy vhodného k přenosu, ohřevu i ke stolování. Výrazné je nádobí na tekutiny - džbány, čutora a poklop (celkem $13 \%)$. Menším množstvím zlomků je zastoupené typické stolovací nádobí - talírovité mísy $(9 \%)$ 


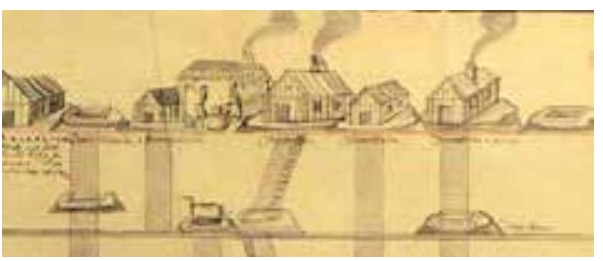

Obr. 8. Detail důlních budov na šachtách, výřez z reprodukce důlní mapy (1586-1590) ze SA Freiberg. Převzato z Wilsdorf 1987, 77.

Abb. 8. Detail von Grubengebäuden oberhalb von Schächten, Ausschnitt aus einer Abbildung einer Grubenkarte (1586-1590) aus dem Bergarchiv Freiberg. Entnommen aus Wilsdorf 1987, 77.

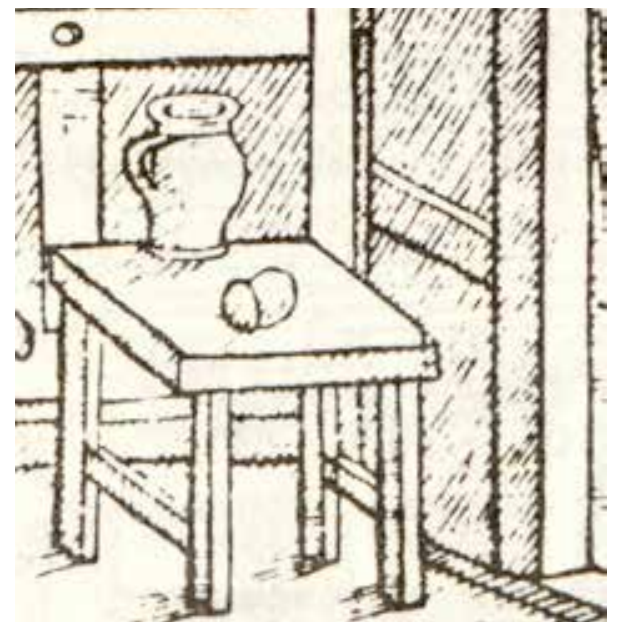

Obr. 9. Detail hrázděného interiéru stoupy s připraveným občerstvením. Podle Hummel a kol. 1933, 271.

Abb. 9. Detail des Innenraums eines Pochwerkfachwerkbaus mit bereitgestellter Erfrischung. Nach Hummel a kol. 1933, 271. a pouze minimální množství patří k nádobí pro prrípravu nebo ohřev potravin - trojnožce (3\%). Celkový vzhled keramického nádobí je po výtvarné stránce chudý, bez jakéhokoliv reprezentativního provedení. Hlavní modelace nejběžnějšího druhu nádobí - hrnce - nese nejvíce profilaci okraje okruží s vnitřním prožlabením pro poklici a jedno ucho. Tato forma hrnců se uplatňovala zejména pro polévané tuhé pokrmy patřící do celodenního režimu stravování (Štajnochr 2004, 802). Ostatní druhy nádobí keramické či nekeramické produkce, s nimiž se setkáváme $\mathrm{v}$ raně novověkých domácnostech různého sociálního prostředí, například pekáče, hračky, hluboké mísy, zdobené výrobky, různé velikosti nádobí, duté sklo, kovové nádobí aj., zde nebyly vůbec př́ítomny (srov. Blažková a kol. 2012). Pro posouzení významu a skladby hrnčin $v$ jejím běžném použití je nutno brát $\mathrm{v}$ úvahu okolnosti, kterými se movitá náplň domácností v raném novověku značně liší od předchozích období. Měštanské domácnosti využívaly kromě hrnčin také v hojné míře kameninových, skleněných a kovových výrobků. Vzájemný podíl v zastoupení jednotlivých druhů zboží se lišil v rámci sociální diferenciace měšt’anů (např. inventáře jáchymovských měšt’anů z 16. století, viz Lorenz 1925, 99-100). Př́ítomnost technické keramiky v haldovině není náhodná a její výskyt je svázán s používáním prubířských testů kvality (výtěžnosti) rudy př́mo na dolech.

\subsection{Chronologické zařazení nálezových soubori̊}

Souhrnné poznatky chronologicky citlivějších zlomků nálezů řadí získaný soubor nálezů jednotně do období 16. až první poloviny 17. století. Díky dochovaným písemným pramenům lze tuto dataci více konkretizovat. Mathesiem zaznamenané údaje o otvírce nálezných žil pro jednotlivé části revíru nás seznamují s rychlostí a relativním postupem prvních, již těžebních prací, bezprostředně navazujících na předchozí prospekční (neboli také kutací) práce (Urban 1981). Ty se na Niklasbergu rozběhly těsně kolem let 1536-1539, tj. pro žíly Rotegang (soubor 2/04), Eliasgang (soubor 9/05) a Johannes Silbermüller (soubory 3/03, 7/05); Geyerská žíla sice byla objevena roku 1517, ovšem v jiné části revíru a práce na ní v prostoru Eliášského údolí (soubory 2/03, 10/05) lze reálněji vztáhnout až k počátku 30. let. Údolí Neklidu (soubor 3/04) a prostor u Seideltaichu (soubor 6/04) přišly na řadu až v průběhu 30. let 16. století. Díky tomu je možné dobře stanovit začátek těžby v daném geografickém prostoru a ad quem určit i spodní chronologickou hranici nálezových souborů. Stanovení zániku dolování je už problematické. Začátek prvních poklesů v těžbě se projevil na nejdříve otevřených žilách již v průběhu druhé poloviny 40. let (Šternberk 1984, 288-289). Nepříznivý stav dolů v důsledku extenzivního postupu těžebních prací s cílem co nejrychleji vydobýt ložisko zapříčinil, že v průběhu druhé poloviny 


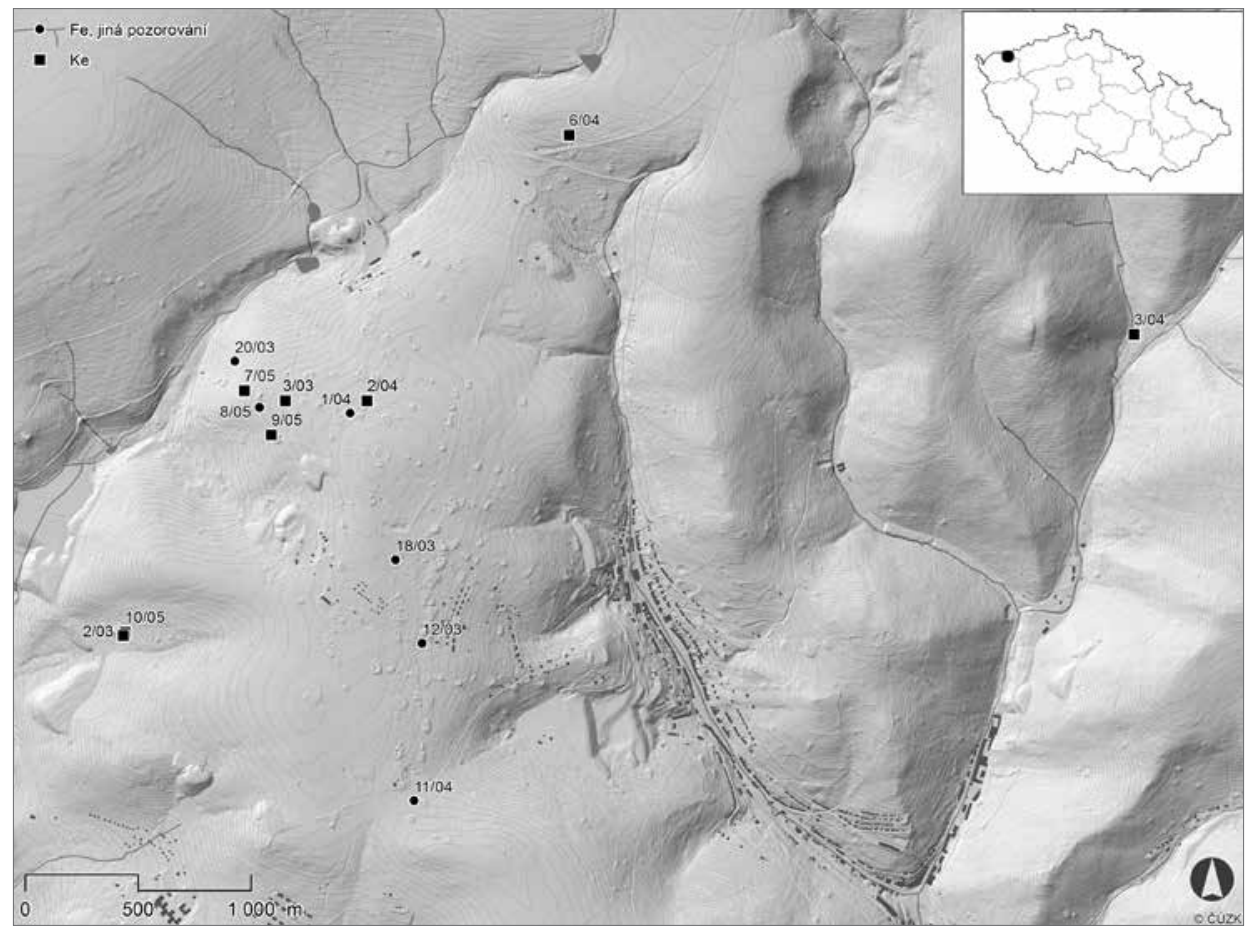

Obr. 10. Mapa LLS s prostorovým vynesením nálezových souborů. Vypracoval O. Malina.

Abb. 10. LLS-Karte mit räumlicher Darstellung der Fundkomplexe. Ausgearbeitet von O. Malina.

16. století pokračovaly práce pouze v okolí a ve směru dědičných štol, a maximálně v 80 . letech téhož století byly zastaveny téměř veškeré důlní práce v revíru (Majer 1967, 160; 1967a, 134).

Pro sledování časového horizontu uložení souborů je důležité upozornit na to, že zjištěné artefakty nelze výhradně ztotožnit se zánikovou fází dolu, odpovídají spíše době aktivního provozu na povrchu prŕslušné šachty nebo štoly, které je možné vymezit obdobím od 30 . let 16 . století po průběh druhé poloviny 16. století, maximálně do počátku 80 . let téhož století. Obnova báňských prací v mladším období byla již vedena v jiném přístupu $\mathrm{k}$ ložisku a odlišné metodě jeho dobývání (k tomu Schenk 1967).

\subsection{Doplňující zjišstění}

V roce 2014 proběhl v jáchymovském revíru nedestruktivní archeologický výzkum pod vedením Ondřeje Maliny z Národního památkového ústavu v Lokti. Výzkum byl doplněn mikrosondážemi, které byly cíleně zaměřeny na vybrané relikty po důlní činnosti, u nichž se sledovaly rozdíly v prostoru a distribuci nálezů a jejich archeologický potenciál. V případě kovových nálezů jsou zajímavé informace o prostorové distribuci. Nálezové situace a získané movité soubory artefaktů ukazují na podobná zjištění (více Malina 2015).

\section{Výpověd' písemných a ikonografických pramenů}

Během 16. století vzniklo v Jáchymově mimořádné společensko-kulturní prostředí, které bylo vysoce podnětné pro řadu učenců té doby. Z oblasti báňské a hutní problematiky čerpali poznatky a vědomosti pro své odborné či odborně-populární práce zejména Georgius Agricola 
a Johannes Mathesius. Prvořadý význam děl těchto autorů tkví v zachované autentičnosti samotného jáchymovského báňského i městského prostředí 16. století. Zároveň nelze opomenout další dobové dochované písemné zdroje, jako jsou báňské řády, knihy propůjček, úřední korespondence aj. Po patřičné kritičnosti k nim lze přistoupit jako k cenné pramenné základně. Pro poznání jáchymovského důlního prostředí je nutné vyzdvihnout níže uvedená díla, z nichž lze čerpat užitečné informace, které již archeologické prameny nepřináší. Jedná se o dvě práce Agricoly - Bergmannus, sive de re metallica (Reiniš 1933) a De re metallica libri XII (Dvanáct knih o hornictví a hutnictví, Hummel a kol. 1933), dále o Mathesiovu práci Sarepta oder Bergpostilla (Urban 1981), jáchymovský báňský řád Štěpána Šlika z roku 1518 (Jangl 1979, 118-157, 164-167) a báňský řád Ferdinanda I. Habsburského z roku 1548 (Jangl 1978).

\subsection{Rozbor obsahu písemných a ikonografických pramenů}

Následující kapitola je sestavena z citací textů, které se vztahují ke sledované problematice podoby a charakteru důlní zástavby, movitému inventáři a případně i reáliím každodenního pracovního dne na dolech. Hlavním záměrem je poznat ty skutečnosti, které se již v archeologických pramenech nezachovaly nebo během archeologizace kontextů zcela zanikly.

Ucelený postup výstavby důlní zástavby od okamžiku nálezu žíly, momentu její potřeby a základních požadavků na důlní zástavbu je názorně vidět v této pasáži: „Hornik po objevení hlubinné žily započne hloubit šachtu a nad ní postaví vrátek, šachetni boudu, aby lidé, kteři otáčejí vrátkem, nemrzli a nebyli deštěm obtěžováni. Kladou do ní vozíky, horníci své nářadí a jiné věci ukrývají. Vedle důlní boudy stavi se druhá budova, v níz bydli důlní a jiní horníci a do niž se ukládá hmota rudní. Ačkoliv někteři dělaji jednu boudu, tu někdy chlapci nebo nějaká zvírata podají do dolu, většina horníkư umistuje odděleně jednu od druhé nebo je alespoň stěnou odděluje“ (Hummel a kol. 1933, 81). Detailnější popis požadavků na stavební provedení důlních budov se zřetelem na důležité části konstrukcí, např́klad dveře či takové detaily, jako byl význam orientace vstupu, je vidět v těchto dvou pasážích: „Potom dveře di̊lního domu necht nejsou obráceny $k$ severu, aby v zimé mrazem žebřiky nezmrzly. Nebo se stalo, ruce zkřehlé mrazem nebo kluzké by se neudržely" (Hummel a kol. 1933, 188). V dalším textu se vedle toho také dovídáme o požadavcích na kvalitu samotné nadzemní konstrukce a na její nezbytné vnitřní vybavení v podobě různých věder, kýblů a truhel na rudy, viz: „Šichtmistři maji dbát na to, aby v̌̌echny doly, na kterých se rube ruda, byly pokud možno uzamčeny, roubeni dobré a pevné, uvnitř postaven pevný zamčený truhlik, dobrá ruda uložena $v$ něm a stoupována při uzavřených dveřich“ (Jangl 1979, 131/čl. 41). A dále: „Necky vytahuje naddůlní, aby je odnesl do blizké budovy. Co tu vidim věder a necek! Ve všech nádobách je rudní materie stříbra" (Reiniš 1957, 96). Také: „(...) co je na odvalu kolem baráku? (...) budovy důlního na tomto dole (...). Co je tu necek a bedniček se střibrnou rudou" (Reiniš 1957, 150). Kvalitní, bohaté nálomy stř́ibrné rudy se již v dole nakládaly zvlášt' a vytahovaly se na povrch v uzavřených nádobách, jak vidíme na tomto př́íkladě: „,...) dobrá ruda se má vytahovat v dobře uzavřených kýblech (...)“ (Jangl 1979, 126 čl. 26). V dalším textu se dovídáme o účelu staveb na dolech, tzv. důlní zástavby, která zahrnovala stavby sloužící pouze provozním účelům: „Jinak nemá být na žádném dolu postaven nějaký velký dům, nýbrž jen k obyčejné potřebě a také se nemá na žádném dolu šenkovat" (Jang1 1979, 131 čl. 41; 1978, 52-53 čl. 48). Zajímavým poznatkem o stravovacím režimu horníků je již důrazně prosazovaný zákaz šenkování alkoholických nápojů, hlavně piva, a dále snaha odbourat nedobré zvyklosti v podobě poskytování ubytování i stravy svým zaměstnancům ze strany nadřízených, viz: „Žádný šichtmistr nebo důlní nesmí žádného dělníka nebo haviře nutit (...), aby se u něj stravoval či pil (...), aby žádný nedržel na bytě mládence, havíre nebo pacholky (...), nemá odvážit na dolech šenkovat pivo nebo držet strávniky“ (Jangl 1978, 50 čl. 44). Vedle výše uvedených staveb důlních bud a budov se na dolech také vyskytovaly žentoury, jejichž základním rysem byla velká mohutnost: „Vidím nový, neobvyklý tvar domu (...). Tato budova byla vystavěna nad jámou, která uštědřuje veliké bohatství (...), ale proč se tato stavba liší od ostatnich důlních budov? (...) Hned to pochopís, vstupme! (...) Proboha, jaký to zde vidím ohromný stroj (...)“ (Reiniš 1957, 87-89). 


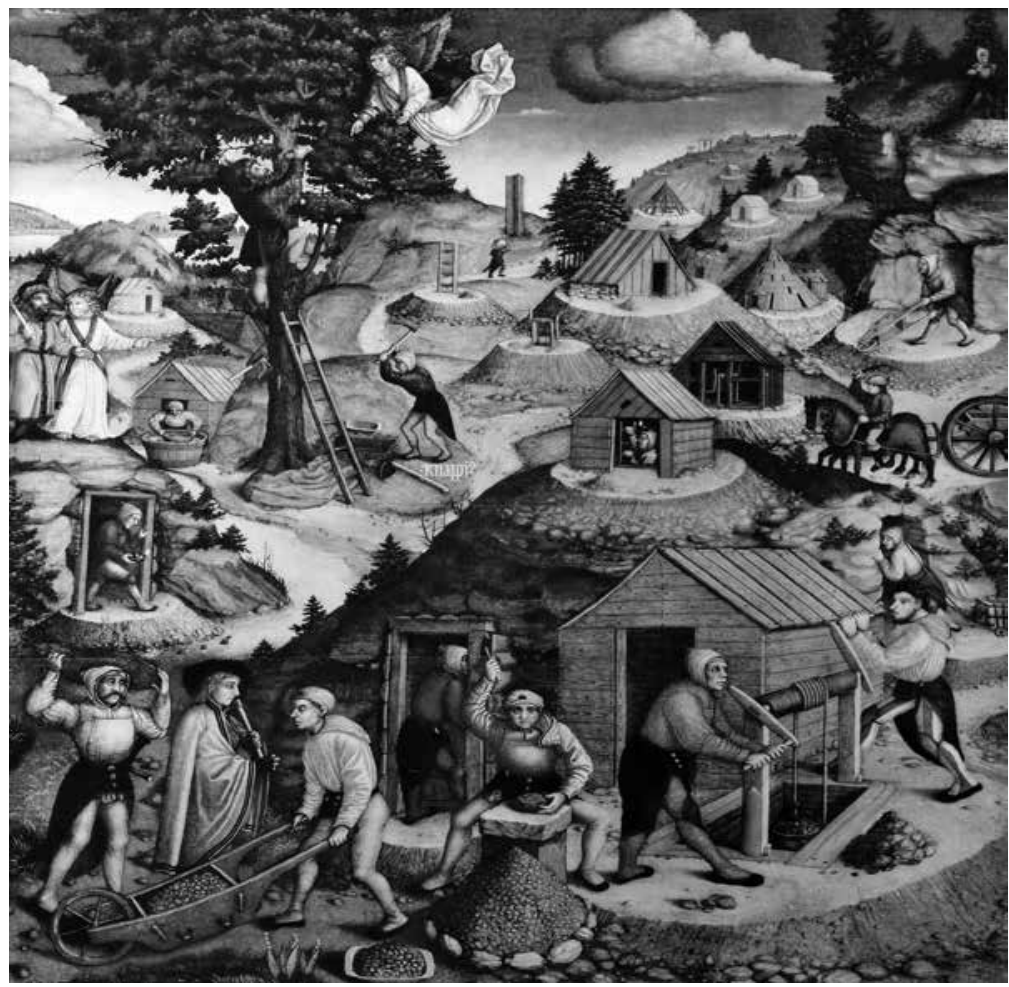

Obr. 11. Reprodukce deskového oltáře kostela sv. Anny v Annabergu od H. Hesse z roku 1521. Převzato z Wilsdorf 1987, úprava O. Malina.

Abb. 11. Ausschnitt des Tafelaltars der St. Annen-Kirche in Annaberg von H. Hesse aus dem Jahr 1521. Entnommen aus Wilsdorf 1987 , bearbeitet von O. Malina.

Vizuální podoba celého komplexu důlní krajiny krušnohorské oblasti v první polovině 16. století je nejvýstižněji zachycena na reprodukci deskového oltáře kostela sv. Anny v Annabergu od Hanse Hesse z roku 1521 (obr. 11) a rytinách doprovázejících dílo Georgia Agricoly De re metallica XII. libri (Hummel a kol. 1933). K těmto dvěma základním dílům se zachovalo nepříliš velké množství dalších, vesměs dílčích vyobrazení důlních map nebo revírů v různé kvalitě i podrobnosti záznamu, např́iklad důlní mapa ze saského archivu ve Freibergu (obr. 8). Přesto, že tato zobrazení důlní zástavby vždy zohledňují ty skutečnosti, které byly záměrem k jejich zhotovení, mají jeden společný a výrazný prvek a tím je výslovná účelovost k pracovní, nikoli obytné funkci. Všechny nadzemní konstrukce, at' ve formě lehkých přístřešků, či uzavřených a kvalitně stavěných budov, vycházely z potřeb dolů, tj. hlavně těžby, a také zpracovatelských aktivit přímo navazujících na těžební práce, například třídění rud. V případě protnutí těžebních či zpracovatelských areálů s vlastními obytnými areály docházelo pak nevyhnutelně ke vzájemné konfrontaci, jejímž výsledkem byl jakýsi kompromis a také jiné archeologické situace. To je ale jiné téma, kterým se tento článek nezabývá, ale je mu věnována pozornost jinde (např. Nováček 1994; Schwabenicky 2009; Hrubý 2011).

\subsection{Vyhodnocení poznatkü}

Z textů i vyobrazení je patrné, že na ohlubni šachty (s vrátkem) byla vždy postavena důlní bouda, která poskytovala zázemí pro nářadí a rudu a chránila jak samotné důlní dílo, tak i horníky před nepřízní počasí. Stavba byla pevné, roubené a celodřevěné konstrukce, opatřená 
pevnými dveřmi. Na výjevu důlní krajiny na annaberském oltáři (obr. 11) je také vyobrazen jednoduchý otevřený prrístř̌šek, ovšem otázkou zůstává, jednalo-li se o počáteční fázi těžby, kdy přístřešek mohl po velmi krátkou dobu (maximálně do zimy) předcházet důlní boudě, nebo zdali to byl záměr autora obrazu kvůli lepšímu znázornění. Každopádně v textech i na dalších ikonografických dílech se setkáváme pouze s klasickou důlní boudou, případně cechovním domem. Rudnina se v důlní boudě nebo v cechovním domku ukládala do truhel, věder nebo necek a platilo pravidlo, že čím kvalitnější (ušlechtilejší) ruda, tím lépe s ní bylo nakládáno již od samotného odlomení od žiloviny. V případě vysoce ziskových dolů, kde byla kvůli velkým hloubkám potřeba nasazovat místo vrátků žentoury, se pouze změnilo stavební provedení důlní zástavby, přizpůsobilo se konstrukčnímu řešení daných strojů.

Vedle důlních bud se v těžebním areálu vyskytoval ještě další druh budovy, která vytvářela pracovní zázemí pro důlního, př́ípadně i pro horníky, jejich pomocníky nebo podle potřeby sloužil i k ustájení tažných zvířat a také pro uložení ušlechtilé stř́íbrné rudy. Tento typ domu je znám jako cechovní dům / cáchovna a sloužil i úschově potřebných kresebných materiálů nebo spisů týkajících se provozních záležitostí jednotlivých dolů z celého svěřeného dolového pole. Architektonické řešení cechovního domu však bylo stř́idmé a jeho vzhled i velikost měly vycházet $\mathrm{z}$ potřeb dolů $\mathrm{k}$ němu patřících. Zajímavou změnou pracovní morálky bylo poprvé uplatnění zákazu šenkování př́ímo na dolech již v prvním řádu z roku 1518, doplněné také zákazem ubytovávání a poskytování stravy za úplatu, což byly časté praktiky zaběhnuté v horních revírech se starší tradicí těžby, např́iklad v Kutné Hoře (Pošvář 1978, 21).

Dalšími doplňujícími stavbami vyskytujícími se v nadzemní části těžebních areálů byla různá technická zařízení (např. větrací bubny na vyražených komínech). Jejich zřízení však bylo závislé na vhodné geomorfologii a finančních možnostech těžařstev.

Budování zděných základů pro rozličnou důlní zástavbu nebylo nutné. Dostatečnou drenáž povrchové vody zajištovala haldovina a proti průniku povrchových vod měly šachty nebo štoly ústí chráněná vydřevením celé úvodní části díla. Výdřeva šachet byla zhotovena dřevěnou výztuží ze srubových věnců kladených na sebe nebo v pravidelných odstupech s pažením z prken či fošen. $V$ prŕípadě štol mluvíme pak o dveřejích a celý systém je shodný. Na nejvyšší nadzemní dřevěný srubový věnec šachty se pak osazoval rám s konstrukcí vrátku (Stočes 1945, 93-94). Vyztužení šachet nebo štol nebylo s nadzemní krycí zástavbou provázané, nebot' bylo žádoucí, aby byly rozebíratelné a dle potřeby se mohly posunout. Podíváme-li se na důlní domky, pak shledáváme, že byly stavěny téměř výhradně ze dřeva, a to prkenné, srubové nebo roubené konstrukce s uzavíratelnými dveřmi. V budovách sloužily k deponii rudy (zejména bohaté) uzavíratelné truhly, pro rudy nižší kvality stačila jejich úschova v necičkách nebo vědrech při uzavřeném zámku důlního domku. Budovy mohly sloužit i k občasnému přespání, a to důlních nebo horníků. Existenci obytného zázemí pro rodiny horníků přímo u dolů nic nenasvědčuje a vlastně ani báňské právo tomu nepřálo - viz výše citovaný výňatek z řádu z let 1518 a 1541 o zákazu staveb jiných než pro potřeby dolů. $V$ době největšího rozmachu těžby se obytná zástavba města rozprostírala po svazích vysoko nad dno údolí (Reiniš 1957, 70-71). Samotné sídelní zázemí v podobě města nebylo tedy od dolů tak vzdálené a $\mathrm{k}$ denní docházce na doly máme i další konkrétní doklad z Agricoly: „Kdosi, než zbohatl a žil ještě v převeliké nouzi, vystupoval dvakrát i třikrát za den na tento kopec [pozn. autora: Uhelný vrch], aniž si na něco stěžoval. Jakmile mu počalo prát více štěstí, hned si tu stěžoval na těžký vzduch“" (Reiniš 1957, 75).

\section{Celkové shrnutí výsledků}

Výpověd’ archeologických kontextů i movitých artefaktů ukazuje na jejich sepětí s těžebními aktivitami zaměřenými na stř́ibrné rudy. Podle dochovaných údajů o počátku a postupu těžebních prací je možné těžební aktivity a s nimi i studované nálezové soubory chronologicky zařadit do časového rozpětí od 30. let až maximálně po 80. léta 16. století. V archeologických pramenech se bohužel reálie pracovního prostředí a každodenního života odráží jen velmi 
sporadicky či vůbec, např́klad z nadzemních konstrukcí domů se dochovaly z celých staveb pouze zlomky kování, hřebíků, kachlů a okenních skel. Díky komparaci s informacemi obsaženými v dobových písemných a ikonografických pramenech můžeme získat zcela jedinečné poznatky o vlastní důlní zástavbě a projevu každodenní hmotné kultury přímo na důlních pracovištích v průběhu 16. století.

Movité keramické artefakty ukazují na krátkodobé (denní) přechovávání připravené stravy, případně její ohřev a konzumaci (viz obr. 4, 5, 9). Významný je v keramickém sortimentu podíl nádobí pro přechovávání tekutin nealkoholického rázu, zejména kameninových džbánů. Každodenní pracovní život, ohraničený dobou výkonu práce, dokládá i absence jiných výrobků, které doprovází celodenní život několikagenerační rodiny. Docházka horníků na doly z nepř́liš vzdáleného sídelního zázemí vlastního města Jáchymova je podložena i autentickými dobovými zprávami (Reiniš 1957, 75).

Nálezy technické keramiky, tj. několikanásobně přepalované neglazované zlomky a prubířské stř̌epy, mají už přímou souvislost s těžebními pracemi. Prubířské zkoušky byly hlavním postupem ke zjištění výnosnosti zrudnění, popřípadě kvality zhutnělého kovu, a jejich provádění je spíše známé z prostředí zpracovatelských provozů a mincoven (např. Muk-Hus 1985, 236; Hemker-Bock v tisku). Nálezy prubířské keramiky jsou také dokladem fluktuace prubířu na důlních pracovištích, nejspíše podle potřeb jednotlivých dolů.

Ke studiu vzhledu a charakteru vlastní důlní zástavby jsou k dispozici archeologické nálezy drobných kovových předmětů, zejména hřebíků, okenních skel a kachlů. Ty ukazují na výlučné uplatnění nadzemních dřevěných stavebních konstrukcí. S jejich provedením se lze setkat ve formě lehkých nadzemních staveb - přístř̌ešků nebo bud sbitých z prken, ale i uzavřených budov zpravidla roubené nebo hrázděné konstrukce s vytápěným provozem (obr. 6 a 8 ). Názorně to je možno vidět na reprodukcích annaberského oltáře (obr. 11), na němž je zachyceno několik typů důlních a zpracovatelských staveb, nikoli obytných (srovnej s Volf-Zeman 2016, 220). Uvažujeme-li o druhu otopného zařízení, připadá $\mathrm{v}$ úvahu v případě důlních domků nejpravděpodobněji vytápění uzavřeným ohněm, tj. pecí nebo kamny. Malá spotřeba paliva, vysoká výhřevnost, minimalizace požáru a zamezení tahu kouře do podzemních prostor byla u uzavřených otopných těles, v našem případě kachlových kamen, nespornou výhodou (Hazlbauer 1998, 27). Kachlová kamna v nalezeném kontextu nezvyšovala úroveň kulturního prostředí, ale byla odrazem intenzivního celoročního provozu, který v neprríznivém horském klimatu toto zařízení vyžadoval. Dostatečné osvětlení vnitřního prostoru zajišt’ovala okna se skleněnou výplní (obr. 7), v té době vcelku běžná (Sedláčková 2007, 220). Př́itomnost plochého okenního skla a kachlů zároveň upozorňuje u některých budov na takovou stavební kvalitu, která splněním otopných podmínek a dostatečným osvětlením umožňovala dle potřeby celoroční provoz a vytvářela dostačující pracovní zázemí. S tímto typem zástavby se můžeme setkat v 16 . století podle potřeby ve všech těžebních, zpracovatelských či výrobních areálech, at' již se jednalo o úpravny, třídírny rud nebo rýžovnické provozy (např. Hummel a kol. 1933, 272). V rámci nálezových souborů z tohoto příspěvku to mohl být např́ílad cechovní dům (soubory 2/03 s 10/05, 3/03 a 2/04). Samotné nálezy hřebíků a pásovin bez doprovodu kachlů a skla mohou naopak indikovat jednoduchou dřevěnou konstrukci sbitou z prken, vhodnou pro otevřený př́střešek nebo obyčejnou důlní boudu.

Význam a př́inos archeologických pramenů k poznání tak specifické části sídelních areálů, jako je prostředí dolů a důlní krajiny, je nepostradatelný, ale bohužel je také značně limitován vlastním charakterem důlních prací, které ze své podstaty ani neumožňují vznik a dochování statisticky hodnotných nálezových souborů a situací. Dochované autentické ikonografické a písemné prameny umožňují doplnit chybějící údaje v archeologických datech a více přiblížit reálie každodenního života horníků na stř́ibrných jáchymovských dolech 16. století.

Tento příspěvek vznikl v rámci projektu ArchaeoMontan 2018 v Programu na podporu přeshraniční spolupráce mezi Českou republikou a Svobodným státem Sasko 2014-2020 financovaného Evropskou unií z Evropského fondu pro regionální rozvoj. 


\section{Prameny a literatura}

BLAŽKOVÁ, G.-FROLÍK, J.-ŽEGKLITZOVÁ, J., 2012: Early Modern archaeological assemblages from Prague Castle and period written and iconographic sources, Studies in Post-Medieval Archaeology 4, 189-132.

HAZLBAUER, Z., 1998: Krása středověkých kamen. Odraz náboženských idejí v českém uměleckém řemesle. Praha.

HEMKER, CH.-BOCK, S., v tisku: Das Franziskanerkloster zu Annaberg und die Nutzung der Anlage nach der Säkularisierung im Jahr 1540, Mitteilungen der Deutschen Gesellschaft für Archäologie des Mittelalters und der Neuzeit 31.

HEMKER, CH.-BURGHARDT, I.-HÖNIG, H., 2014: Annaberg revisited - Archäologische Beobachtungen zum Altbergbau in Annaberg. In: ArchaeoMontan 2013. Krušná krajina, Arbeits- und Forschungsberichte zur sächsichen Bodendenkmalpflege, Beiheft 28, 55-68. Dresden.

HOFMANN, G., 1987: K populačnímu vývoji Jáchymova v 16. století, Studie z dějin hornictví 19, $72-87$.

HORÁK, V., 2000: Mineralogické bohatství ložiska Jáchymov, Minerál VII, č. 3, 187-198.

HRUBÝ, P., 2011: Jihlava - Staré Hory. Archeologický výzkum středověkého důlního, úpravnického a obytného areálu v letech 2002-2006. Dissertationes Archaeologicae Brunenses/Pragensesque 9. Praha - Brno.

HUMMEL, J.-JEŽEK, B., 1933: Jiřího Agricoly Dvanáct knih o hornictví a hutnictví. Matice hornicko-hutnická. Praha.

JANGL, L., 1968: Ložiska cínových rud v Krušných horách, 4. část. Předběžné zhodnocení báňských prací a ložisek cínových rud v blatenském žulovém masívku. Evidenční číslo IV-7, Geofond Kutná Hora, nepublikovaná zpráva, rkp. ulož. v Geofond Praha, archiv posudků GF P021135.

- 1972: Ložiska cínových rud v Krušných horách, 7. část. Vývoj dolování na jih až jihovýchod od Potůčků. Evidenční číslo IV-7, Geofond Kutná Hora, nepublikovaná zpráva, rkp. ulož. v Geofond Praha, archiv posudků GF P024646.

- 1978: Edice České horní právo. 3) Jáchymovský báňský řád 1548. Př́íbram.

- 1979: Edice České horní právo. 4) Báňské řády. Př́ibram.

- 2006: Staré hornické a hutnické míry a váhy. Sokolov.

KLÍR, T., 2016: Sociální kontext slovansko-německého jazykového kontaktu. Severovýchodní Bavorsko a Chebsko v raném středověku - Der soziale Kontext des slawisch-deutschen Sprachkontakts. Nordostbayern und das Egerland im Frühmittelalter, AH 41, 301-337.

KOŘAN, J., 1955: Přehledné dějiny československého hornictví. Praha.

- 1967: Jáchymovské ložisko v minulosti a dnes. I. Jáchymovské ložisko v minulosti. In: Sborník pro dějiny přírodních věd a techniky XII, 35-75. Praha.

- 1967a: K vývoji jáchymovského dolování. I. Počátky Jáchymova a jeho cesta ke slávě. In: Sborník pro dějiny prŕrodních věd a techniky XII, 7-33. Praha.

LORENZ, H., 1925: Bilder aus Alt-Joachimsthal. Umrisse einer Kulturgeschichte einer erzgebirgischen Bergstadt im sechzehnten Jahrhundert. St. Joachimsthal.

MACEK, J., 2001: Jagellonský věk v českých zemích (1471-1526). 1-2. Praha.

MAJER, J., 1967: Jáchymovská důlní technika v minulosti. I. Jáchymovská důlní technika 16. a 17. století. In: Sborník pro dějiny prŕrodních věd a techniky XII, 137-164. Praha.

- 1967a: K problematice báňské techniky 16. století v Jáchymově. In: Dolování v Jáchymově 1516-1966. Rozpravy NTM 26, 128-140. Praha.

- 1968: Těžba stříbrných rud v Jáchymově v 16. století. In: Sborník NTM V, 111-278. Praha.

MALINA, O., 2015: Poznámky k hornické krajině jáchymovského revíru - Anmerkungen zur Montanlandschaft des Reviers von Jáchymov (Joachimstal), AZČ 9, 147-163.

MINISTR, J., 1962: Z minulosti jáchymovských lesů, Minulostí západočeského kraje I, 205-220.

MUK, J.-HUS, M., 1985: Objev pozdně středověké pece mincovny v Jáchymově, AH 10, 235-237.

NEMEŠKAL, L., 1964: Jáchymovská mincovna v první polovině 16. století (1519/20-1561). Praha.

NOVÁČEK, K., 1994: Hornická sídliště - příspěvek ke studiu středověkého neagrárního osídlení. In: Mediaevalia Archaeologica Bohemica. PA - Supplementum 2, 158-170. Praha.

- 2000: Středověký dům v Plzni. Archeologický výzkum parcely v Sedláčkově ul. 1 (čp. 187) - Die Mittelalterliche Haus in Plzeň. Archäologische Erforschung der Parzelle Sedláčkova Strasse 1, Sborník Západočeského muzea v Plzni - Historie XV, 5-66.

ONDRUŠ, P. a kol., 2003: Ondruš, P.-Veselovský, F.-Gabašová, A.-Hloušek, J.-Šrein, V., Geology and hydrothermal vein system of the Jáchymov (Joachimsthal) ore district, Journal of the Czech Geological Society 48 , č. 3-4, 3-18. 
PARMA, J. B., 1962: Vznik dobývacích metod v rudném hornictví a jejich vývoj do konce 19. století. In: Sborník pro dějiny přírodních věd a techniky VII, 137-158. Praha.

- 1970: K historickému vývoji otvírky a př́ípravných prací v rudném hornictví. In: Z dějin hornictví a hutnictví. Rozpravy NTM, 59-68. Praha.

POŠVÁŘ, J., 1978: Společenské vztahy v Ius regale montanorum, Studie z dějin hornictví 9, 15-28.

RADA, O., 1958: Pozdně gotický dům v Jáchymově, ZPP XVIII, 31-36.

REINIŠ, J., 1957: Georgius Agricola: Bermannus aneb Rozmluva o hornictví (Kettner, R., ed.). Praha.

SEDLÁČKOVÁ, H., 2007: From the Gothic period to the Renaissance. Glass in Moravia 1450-circa 1560, Studies in Post-Medieval Archaeology 2, 211-226.

SCHEIDEMANTEL, D.-SCHIFER, T., 2005: Waldenburger Steinzeug. Archäologie und Naturwissenschaften, Landesamt für Archäologie. Band 44. Dresden.

SCHENK, J., 1967: Jáchymovská důlní technika v minulosti. II. Jáchymovská důlní technika v 18. až 20. století. In: Sborník pro dějiny přírodních věd a techniky XII, 165-199. Praha.

SCHMIDT, R., 1913: Soupis památek historických a uměleckých v království Českém od pravěku do polovice XIX. století. XL. Politický okres Jáchymovský. Praha.

SCHWABENICKY, W., 2009: Der mittelalterliche Silberbergbau im Erzgebirgsvorland und im westlichen Erzgebirge unter besonderer Berücksichtigung der Ausgrabungen in der osten Bergstadt Bleiberg bei Frankenberg. Chemnitz.

STOČES, B., 1945: Základy hornictví. Praha.

ŠTAJNOCHR, V., 2004: Hrnce pro tepelné zpracování pokrmů. Studia funkcí novověké keramiky, ASČ 8, $801-851$.

ŠTERNBERK, K., 1984: Nástin dějin českého hornictví. I. svazek. Př́íbram.

URBAN, J., 1981: Johannes Mathesius: Sarepta oder Bergpostill Sampt der Jochimßthalischen kurtin Chroniken. Hornická postila s krátkou jáchymovskou kronikou, I.-II. díl. Komitét symposia Hornická Příbram ve vědě a technice, Př́bram a NTM Praha.

- 1987: K počátkům dolování v Jáchymově, Studie z dějin hornictví 19, 61-69.

VITOUŠ, P., 1974: Lazar Ercker: Kniha o prubířství. Fontes Bibliographiae 6. Praha.

VOLF, M.-ZEMAN, L., 2016: Krušnohorská architektura a urbanismus. Nové poznatky k počátkům horního města Jáchymova. In: Dějiny staveb. Sborník př́íspěvků z konference Dějiny staveb 2016, 220-228. Plzeň.

WILSDORF, H., 1987: Montanwesen. Eine Kulturgeschichte. Leipzig.

ZÁMEK, J., 1989: Závěrečná zpráva úkolu Jáchymov - Poddolování 018751 47. Geoindustria, s. p., Praha, nepublikovaná zpráva, rkp. ulož. v Geofondu Praha, archiv posudků, GF P077260.

ZEMAN, L., 2016: Historie stavebního vývoje a architektury města Jáchymova. 500 let města Jáchymova. Jáchymov.

ŽEGKLITZ, J., 2012: Prints and other artwork models for motifs on stove tiles from the Czech lands. Renaissance stove tiles as a means for disseminating ideas and culture during the age of Reformation, Studies in Post-Medieval Archaeology 4, 25-111.

\section{Zusammenfassung}

\section{Archäologische Funde aus Grubenarealen des 16. Jahrhunderts in Jáchymov/Joachimsthal}

Der vorliegende Beitrag ist einer Gruppe von Funden und dem Charakter der Bebauung einer Grubenumgebung gewidmet. Die Stadt Jáchymov/Joachimsthal (Bezirk Karlovy Vary/Karlsbad) befindet sich im Westteil des böhmischen Erzgebirges, und ihre Gründung und Entwickung im 16. Jahrhundert ist mit dem Abbau von Silbererzen verbunden. In den Jahren 2003-2010 wurde im Erzrevier Jáchymov eine archäologischen Untersuchung der Geländerelikte der Bergwerke durchgeführt.

Diese Untersuchung ergab mehrere Fundgruppen mit Keramikfunden, die ausschließlich von Montanbetrieben stammen (Abb. 10). Die Fundgruppen sind geringen Umfangs und die entdeckten Keramikfunde lassen sich in folgende Kategorien untergliedern: Töpferware (75\%), Steinzeug (8\%), technische Keramik (5\%) und Kacheln (12\%), siehe Tabelle 1. Von der Töpferware bildet Oxidationsware mit Innenglasur (JACH101 bis 103) den Grundstock, ihr Formenbestand wird in Diagramm 1 wiedergegeben. Diese Produktion wird von der weniger oft vertretenen unglasierten 
Oxidationsware (JACH104; Diagramm 2) ergänzt. Eine sehr geringe Menge zählt zur Reduktionskeramik (JACH106). Steinzeugerzeugnisse stellen eine beträchtliche Ergänzung der Töpferware dar (JACH301, 302, 304 und 305; Diagramm 3) Im gesamten Sortiment der Küchenproduktion dominieren Töpfe (58\%) vor Deckeln (17\%), deutlich vertreten ist auch für Flüssigkeiten bestimmtes Geschirr (13\%), weniger ist für Schüsseln (9\%) und den Dreifuß bestimmt (3\%), siehe Diagramm 4. Diese Zusammensetzung gibt zusammen mit dem Warensortiment Aufschluss über die tägliche Verpflegung auf Gruben, ggf. darüber, wie mitgebrachte Speisen erwärmt wurden. Ferner wurden auch technische Keramik und Probierscherben entdeckt (Abb. 2:3 und 4), welche nach Bedarf auch das Bewegungsspektrum von Probierern direkt in den Gruben belegen.

Bruchstücke von Napf- und Blattkacheln, Glas und kleinen Metallgegenständen liefern Aussagen über die Ausstattung der Grubenbebauung. Das reale Bild einer Bebauung im Grubenumfeld kann bzgl. Joachimsthal anhand von einigen zeitgenössischen Werken authentisch studiert werden. Es handelt sich um die Werke von G. Agricola (Bergmannus, sive de re metallica und De re metallica libri XII), J. Mathesius (Sarepta oder Bergpostill) und um die erste Joachimsthaler Bergordnung von Stefan Schlick aus dem Jahr 1518 (Jangl 1979, 164-167), dazu ergänzend sind die Tafelgemälde des Annaberger Bergaltars von H. Hesse (Abb. 11) und eine Grubenkarte im sächsischen Bergarchiv Freiberg (nach Wilsdorf 1987, 77; Abb. 8) bedeutende ikonographische Quellen. Die Kombination von zeitgenössischen Illustrationen und Literatur zeigt übersichtlich auf, dass die direkt an der Haldenmasse liegende eigentliche Grubenbebauung verschieden war und sich nach dem Umfang und der Fortgeschrittenheit der Abbauarbeiten richtete. Die Grubenbebauung über Schächten oder an Stollen hatten den Charakter von oberirdischen Baukonstruktionen aus Holz. Ihrer Ausführung kann man in Formen begegnen, angefangen bei leichten oberirdischen Bauten wie Schutzdächer oder Bretterverschläge bis hin zu geschlossenen Objekten, die in der Regel eine Blockbau- oder Fachwerkkonstruktion mit beheiztem Betrieb aufweisen (siehe Abb. 6, 8, 11). Die Kachelöfen haben im vorgefundenen Kontext nicht das Niveau eines kulturellen Umfeldes gehoben, sondern spiegelten einen intensiven ganzjährigen Betrieb wider, der im rauhen Bergklima eine solche Ausstattung erforderlich machte. Eine ausreichende Beleuchtung des Innenraums wurde durch Fenster mit Glasfüllung gewährleistet (Abb. 7), was im mitteleuropäischem Raum jener Zeit gängig zu sein pflegte (Sedláčková 2007, 220). Das Vorhandensein von flachem Fensterglas und von Kacheln weist bei einigen Gebäuden gleichzeitig auf eine solche bauliche Qualität hin, welche durch Erfüllung der Heizbedingungen und die ausreichende Beleuchtung nach Bedarf einen ganzjährigen Betrieb ermöglichte und ein ausreichendes Arbeitsumfeld schuf. Diesem Bebauungstyp können wir im 16. Jahrhundert in allen Abbau-, Verarbeitungs- oder Produktionsarealen begegnen, gleich, ob es sich dabei um Aufbereitungsanlagen, Erzsortieranlagen oder Waschbetriebe handelte (z.B. Agricola 1556, 272). Im Rahmen des Fundkomplexes des vorliegenden Beitrags konnte es beispielsweise ein Zunfthaus gewesen sein (Komplexe 2/03 und 10/05, 3/03 und 2/04). Isolierte Funde von Nägeln und Bandeisen ohne die Begleitung von Kacheln und Glas können umgekehrt auf die einfache Konstruktion eines Bretterverschlags hindeuten, die sich für offene Schutzdächer oder gewöhnliche Grubenhütten eignete.

Der vorliegende Beitrag entstand im Rahmen des Projektes ArchaeoMontan 2018 des von der Europäischen Union in den Jahren 2014-2020 aus dem Europäischen Fonds für regionale Entwicklung finanzierten Programmes zur Förderung der grenzübergreifenden Zusammenarbeit zwischen der Tschechischen Republik und dem Freistaat Sachsen.

Mgr. Pavlína Schneiderwinklová, Národní památkový ústav, ÚOP v Lokti, Kostelní 81/25, 35733 Loket, Česká republika, pavlina_ss@seznam.cz

Mgr. Ondřej Malina, Ph.D., Národní památkový ústav, ÚOP v Lokti, Kostelní 81/25, 35733 Loket, Česká republika,malina.ondrej@npu.cz

Mgr. Markéta Augustýnová, Národní památkový ústav, ÚOP v Lokti, Kostelní 81/25, 35733 Loket, Česká republika,augustynovam@seznam.cz 


\section{Příloha 1. Deskripce keramických tříd. Region západní Krušnohoří}

(kód tř́ídy - barva; materiál; příměsi; technologické stopy; úprava povrchu; výpal; poznámka)

\section{1. kuchyňská keramika}

JACH101 - světlá žlutá, světlá béžová, bílošedá; hlína; křemičitý písek do $0,5 \mathrm{~mm}$ a slída ojediněle; modelační rýžky přecházející do nízké vývalkové šroubovice; Pb-glazura vnitřní; $\mathrm{O}$, tvrdý

JACH102 - světlá žlutá, světlá okrová, bílošedá; hlína; křemičitý písek do $1 \mathrm{~mm}$ četně a slída ojediněle; modelační rýžky přecházející do nízké vývalkové šroubovice; Pb-glazura vnitřní; O, tvrdý

JACH103 - světlá červená, růžová; hlína; křemičitý písek do $0,5 \mathrm{~mm}$ a slída ojediněle; modelační rýžky přecházející do nízké vývalkové šroubovice; Pb-glazura vnitřní; $\mathrm{O}$, stř̌edně tvrdý

JACH104 - světlá béžová, světlá okrová; hlína; křemičitý písek do 0,5 mm a slída mírně až četně; modelační rýžky přecházející do nízké vývalkové šroubovice; neglazováno; $\mathrm{O}$, středně tvrdý

JACH105 - světlá žlutá, světlá okrová, bílošedá; hlína; křemičitý písek do $0,5 \mathrm{~mm}$ a slída ojediněle; modelační rýžky; Pb-glazura oboustranná, prŕípadná engoba; $\mathrm{O}$, tvrdý

JACH106 - světlá šedá; hlína; křemičitý písek do $0,5 \mathrm{~mm}$ a slída mírně až ojediněle; modelační rýžky; neglazováno; R, tvrdý

\section{2. kamnová keramika}

JACH201 - bílošedá; hlína; křemičitý písek 1-2 mm a slída mírně až ojediněle; neglazováno; O, tvrdý

JACH202 - světlá hnědá - načervenalá; hlína; křemičitý písek do $0,5 \mathrm{~mm}$ a slída ojediněle; neglazováno; O, středně tvrdý

JACH203 - světlá hnědá - načervenalá; hlína; křemičitý písek do $0,5 \mathrm{~mm}$ a slída ojediněle; $\mathrm{O}$, střední

JACH204 - světlá šedobílá; hlína; křemičitý písek do $0,5 \mathrm{~mm}$ a slída ojediněle; Pb-glazura vnější; $\mathrm{O}$, tvrdý

JACH205 - světlá cihlově červená; hlína; křemičitý písek do $0,5 \mathrm{~mm}$ ojediněle; Pb-glazura vnitřní s engobou; $\mathrm{O}$, tvrdý

JACH206 - střední šedožlutá; hlína; křemičitý písek do $0,5 \mathrm{~mm}$ četně; neglazováno; O/R, tvrdý

\section{3. kamenina}

JACH301 - světlá žlutošedá; jíl; bez makroskopických příměsí; slinutý střep, modelační rýžky; solná glazura ne vždy; R, tvrdý; horší výpal - dutinky v materiálu

JACH302 - střední šedá; jíl; bez makroskopických příměsí; slinutý střep, modelační rýžky; solná glazura ne vždy; R, tvrdý

JACH303 - hnědošedá; jíl; bez makroskopických př́iměsí; slinutý střep, modelační rýžky; solná glazura černohnědé barvy; R, tvrdý; Falkeho skupina

JACH304 - střední šedá; jíl; natavený křemičitý písek 2-3 mm mírně; slinutý střep, modelační rýžky; solná glazura ne vždy; R, tvrdý

JACH305 - světlá žlutošedá; jíl; slinutý střep s nataveným křemičitým pískem 2-3 mm, mírně; modelační rýžky; solná glazura, ne vždy; R, tvrdý; horší výpal - dutinky v materiálu

JACH306 - tmavá béžovošedá; jíl; příměs křemičitého písku do $0,5 \mathrm{~mm}$ mírně; modelační rýžky, při tenké síle střepu slinutý, u silnějšího částečně slinutý; glazura, ne vždy; $\mathrm{O} / \mathrm{R}$, tvrdý poloslinutý; vzhled podobný hrnčině

JACH307 - světlá šedobílá; jíl; bez makroskopických příměsí; slinutý střep, modelační rýžky; bez glazury; R, tvrdý

\section{4. technická keramika}

JACH401 - žlutá, světlá okrová, bílošedá; hlína; křemičitý písek do $0,5 \mathrm{~mm}$ mírně a do $1 \mathrm{~mm}$ ojediněle, slída ojediněle; modelační rýžky; neglazováno; O, tvrdý

JACH402 - žlutá, světlá okrová, bílošedá; hlína; křemičitý písek do $1 \mathrm{~mm}$ četně, slída ojediněle; modelační rýžky; neglazováno; O, tvrdý

JACH403 - světlá žlutá, světlá okrová, bílošedá; hlína; křemičitý písek do $1 \mathrm{~mm}$ a slída ojediněle; neglazováno; O, tvrdý; prubířská keramika

JACH404 - světlá cihlově červená; hlína; křemičitý písek do 1 mm ojediněle, slída, četně; neglazováno; O, tvrdý; prubířská keramika

\section{5. jiná}

JACH501 - šedobílá; kaolinický jíl; bez makroskopických příměsí; neglazováno; R, tvrdý; dýmkařská produkce

\section{6. stavebni keramika}

JACH601 - střední cihlově červená až okrová; hlína; křemičitý písek do 2 mm mírně; neglazováno; O, tvrdý JACH602 - střední cihlově červená až okrová; hlína; křemičitý písek nad $2 \mathrm{~mm}$ a slída mírně; neglazováno; O, tvrdý 
